\title{
INFLUÊNCIA DE SISTEMAS DE MANEJO NA PRODUÇÃO E NAS RESERVAS DE PESSEGUEIRO PRECOCE (Prunus pérsica (L.) Batsch.) CULTIVADO EM CLIMA TROPICAL
}

\author{
joão Paulo Campos de Araujo
}

Dissertação apresentada à Escola Superior de Agricultura "Luiz de Queiroz", Universidade de São Paulo, para obtenção do título de Mestre em Agronomia, Área de Concentração: Fitotecnia.

\author{
P I R A C I C A B A \\ Estado de São Paulo - Brasil \\ Dezembro - 2004
}




\title{
INFLUÊNCIA DE SISTEMAS DE MANEJO NA PRODUÇÃO E NAS RESERVAS DE PESSEGUEIRO PRECOCE (Prunus pérsica (L.) Batsch.) CULTIVADO EM CLIMA TROPICAL
}

\author{
JoÃo Paulo Campos de Araujo \\ Engenheiro Agrônomo
}

Orientador: Prof Dr. JOÃO ALEXIO SCARPARE FILHO

Dissertação apresentada à Escola Superior de Agricultura "Luiz de Queiroz", Universidade de São Paulo, para obtenção do título de Mestre em Agronomia, Área de Concentração: Fitotecnia.

\author{
P I R A C I C A B A \\ Estado de São Paulo - Brasil \\ Dezembro - 2004
}




\section{Dados Internacionais de Catalogação na Publicação (CIP)}

DIVISÃO DE BIBLIOTECA E DOCUMENTAÇÃO - ESALQ/USP

Araujo, João Paulo Campos de Influência de sistemas de manejo na produção e nas reservas de pessegueiro precoce (Prunus pérsica (L.) Batsch.) cultivado em clima tropical / João Paulo Campos de Araujo. - - Piracicaba, 2004.

60 p. : il.

Dissertação (Mestrado) - - Escola Superior de Agricultura Luiz de Queiroz, 2004.

Bibliografia.

1. Clima tropical 2. Maturação vegetal - Precoce 3. Pêssego 4. Poda 5. Produção agrícol 6. Regulador de crescimento vegetal 7. Sistema de cultivo - Manejo I. Título

CDD 634.25

\section{"Permitida a cópia total ou parcial deste documento, desde que citada a fonte - $\mathrm{O}$ autor"}


Aos meus pais: Jairo e Samira, pelo apoio incondicional, pelo amor, incentivo compreensão e oportunidade gerada desde a minha infância. Ao meu irmão Cesar pelo companheirismo, apoio amor e incentivo. À minha namorada Milena pelo amor, apoio, confiança, incentivo e compreensão.

\section{DEDICO}




\section{AGRADECIMENTOS}

Ao Prof. Dr. João Alexio Scarpare Filho, pela orientação, auxílio, amizade, compreensão e ensinamentos.

À Escola Superior de Agricultura "Luiz de Queiroz", Universidade de São Paulo, bem como a Comissão do Programa de Pós-Graduação em Fitotecnia pela oportunidade de realização do curso de Mestrado por possibilitar a realização do curso de Mestrado.

À CAPES pela concessão da bolsa de estudos.

Aos funcionários do Departamento de Produção Vegetal, em especial a David, Éder, Aparecido, e às secretárias Célia, Bete, e Luciane, pela atenção e apoio dispensado.

À todos os professores do curso que direta, ou indiretamente auxiliaram na minha formação acadêmica e auxiliaram na elaboração dessa Dissertação.

Ao Prof. Dr. Ângelo Pedro Jacomino, na pessoa de quem agradeço a todos os que compõem o setor de Pós-colheita do departamento por terem disponibilizado aparelhos e auxiliado na realização desse trabalho.

Ao amigo e colega acadêmico Alessandro pelo companheirismo, convivência, apoio e incentivo.

Aos amigos e colegas de curso: Rafael, Raquel, Juliano, Débora, Marcelo, Cecília, Juan, Fernando, Héctor, e a todos os colegas contemporâneos do PPG em fitotecnia pela agradável convivência e amizade.

Ao colega e amigo Carlos pela amizade, convivência, apoio e incentivo.

A Deus, acima de tudo, por nos proporcionar o dom da vida e nos iluminar e guiar nos caminhos nem sempre fáceis de serem trilhados. 


\section{SUMÁRIO}

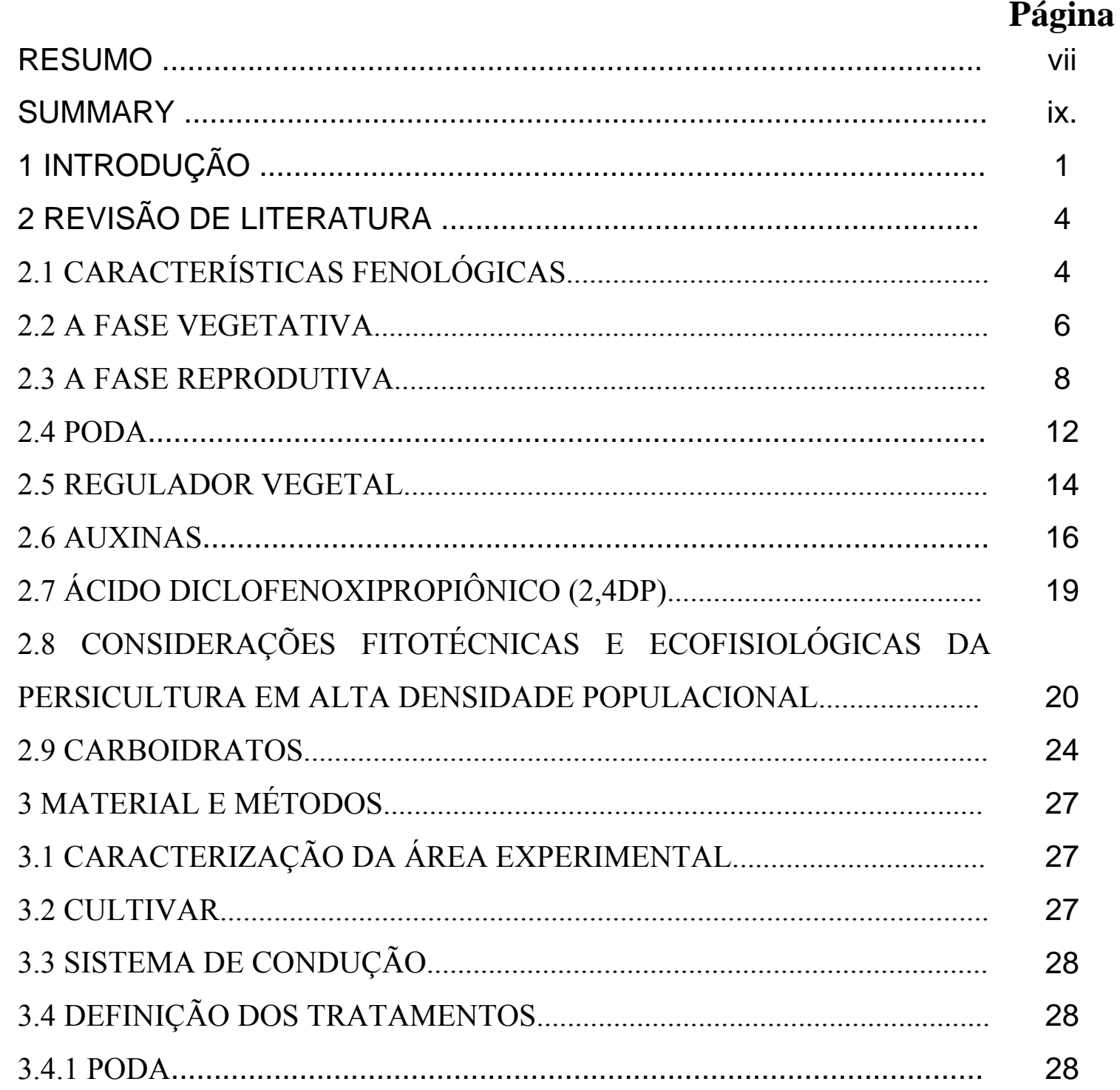


3.4.2 QUEBRA DE DORMÊNCIA............................................................ 29

3.4.3 REGULADOR VEGETAL.................................................................. 30

4 VARIÁVEIS ANALISADAS....................................................................

4.1 CRESCIMENTO DOS RAMOS.........................................................

4.2 CRESCIMENTO DOS FRUTOS....................................................... 31

4.3 FLORESCIMENTO EFETIVO..................................................... 31

4.4 DENSIDADE DE FLORAÇÃO ............................................................... 31

4.5 QUALIDADE DAS FRUTAS.................................................... 31

4.5.1 PESO E TAMANHO DOS FRUTOS........................................... 31

4.5.2 COLORAÇÃO............................................................................

4.5.3 TEOR DE SÓLIDOS SOLÚVEIS TOTAIS........................................ 32

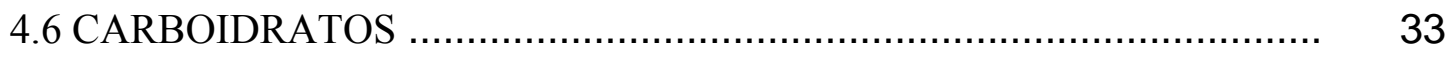

4.6.1 MÉTODO PARA DETERMINAÇÃO DE CARBOIDRATOS NÃO ESTRUTURADOS.................................................................................

4.7 DELINEAMENTO EXPERIMENTAL_........................................................ 35

5. RESULTADOS E DISCUSSÕES............................................................ 36

5.1. CRESCIMENTO DOS RAMOS......................................................... 36

5.2 CRESCIMENTO DOS FRUTOS..............................................................

5.3 FLORESCIMENTO ………………………….................................. 38

5.4 PRODUÇÃO E QUALIDADE DOS FRUTOS ........................................... 40

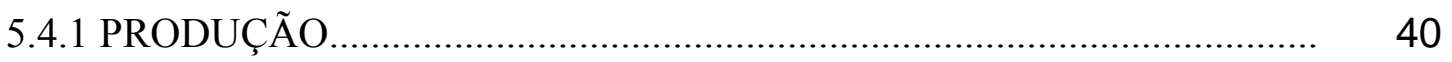

5.4.2 QUALIDADE DOS FRUTOS...............................................................

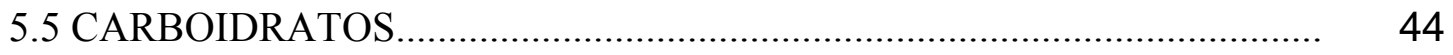

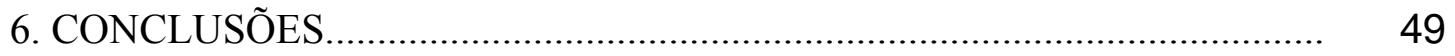

REFERÊNCIAS BIBLIOGRÁFICAS........................................................... 50 


\title{
INFLUÊNCIA DE SISTEMAS DE MANEJO NA PRODUÇÃO E NAS RESERVAS DE PESSEGUEIRO PRECOCE (Prunus pérsica (L.) Batsch.) CULTIVADO EM CLIMA TROPICAL
}

\author{
Autor: JOÃO PAULO CAMPOS DE ARAUJO \\ Orientador Prof. Dr. JOÃO ALEXIO SCARPARE FILHO
}

\section{RESUMO}

A precocidade de maturação é o principal fator de sucesso econômico do persicultor paulista, em vista desse fato existe uma demanda muito grande por novas técnicas que possibilitem a melhoria da qualidade dos frutos e uma maior precocidade na colheita. Este trabalho visa verificar a influência dos sistemas de podas e manutenção das folhas após a colheita nas reservas de carboidratos não estruturados em ramos e raízes do pessegueiro da cultivar Flordaprince,verificar a produção dessas plantas e a qualidade dos frutos em função das reservase verificar a eficiência do uso do regulador vegetal 2,4-DP (ácido diclofenoxipropiônico), em função das reservas de carboidratos solúveis existentes nas plantas, bem como seu possível efeito na qualidade dos frutos obtidos. O trabalho conduzido na Escola Superior de Agricultura "Luiz de Queiroz", em Piracicaba. O delineamento foi de blocos ao acaso, constando de 9 tratamentos e 4 repetições. Cada parcela foi composta por 4 plantas. Os dados foram submetidos as análises de variância e à comparação das médias pelo Teste de Tukey. O espaçamento adotado foi de 3,0 X 1,2 metros, correspondendo a 2777 plantas $a^{-1}$. As plantas foram conduzidas em sistema líder central, e todas receberam as práticas de irrigação, nutrição, quebra de dormência, tratamento fitossanitários, desbrotas, normalmente utilizadas. As podas foram realizadas logo após a colheita, no final de agosto de 2003, quando da 
ocasião da instalação do experimento. Foram coletadas amostras de raízes e ramos,que foram trituradas, secas em estufas, moídas e submetidas à análise de laboratório. Verificou-se os teores de carboidratos solúveis totais no ramo e na raiz das plantas de pessegueiro. $\mathrm{O}$ crescimento dos frutos apresentou a forma de uma curva sigmóide dupla. O tratamento onde não ocorreu desfolha de verão apresentou maior produção de frutos, e maior número de frutos por planta. A aplicação do regulador vegetal 2,4-DP não promoveu aumento significativo nas dimensões dos frutos, causou ainda uma queda no teor de sólidos solúveis e promoveu uma melhora na coloração dos frutos, tanto na face exposta como no fundo do fruto. Ocorreu ainda uma antecipação na colheita em cerda de 7 dias devido a aplicação do regulador vegetal. A concentração de carboidratos solúveis nas raízes e nos ramos flutuou de acordo com a época em que foram coletados, dentro do ciclo da planta, e a concentração nas raízes foi sempre superior àquela encontrada nos ramos. A poda de renovação causou uma queda na produção e um número menor de frutos por planta. 


\title{
INFLUENCE OF SYSTEMS OF HANDLING IN THE PRODUCTION AND IN THE RESERVATIONS OF PRECOCIOUS PEACH TREE (Prunus pérsica (L.) Batsch.) CULTIVATED IN TROPICAL CLIMATE
}

\author{
Author: JOÃO PAULO CAMPOS OF ARAUJO \\ Advisor Prof. Dr. JOÃO ALEXIO SCARPARE FILHO
}

\section{SUMMARY}

The precocity maturation is the main factor of economical success of the producing of peach from São Paulo, in view of that fact the very big demand exists goes new techniques that make possible the improvement of the quality of the fruits and the larger precocity in the crop. This work seeks to verify the influence of the systems of prunings and maintenance of the leaves after the crop in the carboidrates reservations in the structured in branches and roots of the peach tree of cultivating Flordaprince, to verify the production of those plants and the quality of the fruits in function of the reservations to verify the efficiency of the use of the vegetable regulator 2,4-DP (acid diclofenoxipropiônico), in function of the reservations of existent soluble carboidrates in the plants, as well it's possible effect in the quality of the obtained fruits. The work was established at Escola Superior de Agricultura "Luiz of Queiroz", in Piracicaba. The experimental design used was of blocks at random, consisting of 9 treatments and 4 repetitions. Each portion was composed by 4 plants. The data were submitted the variance analyses and to the comparison of the averages for the Test of Tukey. The adopted spacing was of $3,0 \times 1,2$ meters, corresponding to 2777 plants hectare ${ }^{-1}$. 
The plants were driven in system central leader, and all received the irrigation practices, nutrition, numbness break, and treatments to keep healthy plants were maid, sprouts were removed, usually used. The prunings were accomplished soon after the crop, in the end of August of 2003, when of the occasion of the installation of the experiment. Samples of roots and branches, that were collected were triturated, droughts in greenhouses, milled and submitted to the laboratory analysis. It was verified the tenors of total soluble carboidrates in the branch and in the root of the peach tree plants. The growth of the fruits presented the form of a curve double sigmóide. The treatment where didn't happen defoliates of summer presented larger production of fruits, and larger number of fruits for plant. The application of the vegetable regulator 2,4-DP didn't promote significant increase in the dimensions of the fruits, it still caused a fall in the tenor of soluble solids and it promoted an improvement in the coloration of the fruits, in the exposed face and in the bottom of the fruit. It still happened an anticipation in the crop in bristle of 7 days due to application of the vegetable regulator. The concentration of soluble carboidrates in the roots and in the branches it floated in agreement with the time in that they were collected, inside of the cycle of the plant, and the concentration in the roots was always superior that found in the branches. The renewal pruning caused a fall in the production and a smaller number of fruits for plant. 


\section{Introdução}

O pessegueiro encontra-se plantado em diversas regiões com inverno desde bem rigoroso com cerca de 600 a 1200 horas de frio abaixo de $7,2^{\circ} \mathrm{C}$, até em outras praticamente desprovidas de frio hibernal, próximo de 20 horas abaixo de $7,2^{\circ} \mathrm{C}$, embora seja considerada uma planta típica de clima temperado.

A cultivar Flordaprince é uma cultivar de relevância no Estado de São Paulo, segundo dados do Agrianual 2003, o volume comercializado no CEAGESP-SP em 2000 foi de 9.754 toneladas de pêssegos, sendo 4.394 toneladas, cujo ciclo é de 85 a 90 dias, (OJIMA et al.,1984).

Essas cultivares precoces, portanto de ciclo curto, naturalmente não apresentam um bom desenvolvimento em tamanho. Essa característica aliada ao manejo incorreto tem como conseqüência uma grande porcentagem de frutos de tamanhos pequenos. Esse fato ficou evidenciado quando a CEAGESP, através do Programa Paulista para Melhoria dos Padrões Comerciais e Embalagens de Hortifrutigranjeiros (1998) propôs uma nova classificação para o Estado de São Paulo, tendo a classificação dos frutos ampliadas de 3 para 9 classes.

O Brasil possui cerca de 22,8 mil ha plantados com pessegueiros, sendo aproximadamente 12 mil ha só no Rio Grande do Sul. No Estado de São Paulo, segundo levantamento feito pelo Instituto de Economia Agrícola e Coordenadoria de Assistência Técnica Integral, existem aproximadamente 3 mil pés de pêssegos cuja produção é destinada às indústrias, e aproximadamente 60 mil pessegueiros cuja produção visa frutas de mesa. A produção estimada no final da safra 2000/2001 foi de 274 mil quilos de frutos para industria e 8.641 mil caixas de 3,5 quilos para os frutos de mesa. (FAO, 2004). 
O início da safra paulista ocorre, em geral, em época bastante antecipada em relação à dos demais Estados do Sul. Essa precocidade de maturação é decorrente do clima e da utilização de cultivares próprios e técnicas subsidiárias especiais de cultivo. As principais cultivares utilizados em São Paulo produzem normalmente, suas safras de setembro a novembro, disponibilizando ao mercado uma séries de diferentes tipos de pêssegos e de nectarinas.

No Estado de São Paulo, atualmente são cultivadas cerca de duas dezenas de variedades de pêssegos, de excelente qualidade organoléptica, altamente produtivas e dotadas de razoável adaptabilidade. Entretanto, mesmo com o grande avanço no campo do melhoramento, estes cultivares, em sua transição do estádio vegetativo ao frutífero, ainda necessitam da intervenção do fruticultor. Há necessidade de produtos químicos desfolhantes na quebra da dormência das gemas, para que ocorram floração e frutificação uniformes. Nesse particular, a compreensão da sistemática da diferenciação floral e de outros fatores ligados à físiologia da planta torna-se imprescindível aos trabalhos inerentes à completa adaptação da espécie às condições climatoedáficas locais.

De maneira geral, a produção de pêssego no Estado de São Paulo está direcionada ao mercado in-natura, ou seja frutos de mesa. Logo, a qualidade do fruto é de vital importância para que o produto atinja uma cotação melhor, resultando numa melhor remuneração ao produtor. A maior parte da área plantada está instalada com cultivares bem precoces e precoces, cuja safra estende-se de final de agosto até novembro. Esta estratégia adotada pelos produtores tem como meta colocar os frutos no mercado no período da entressafra da produção dos estados do sul do país, evitando assim a concorrência com aquela região.

A precocidade de maturação pode ser considerada como o principal fator de sucesso econômico ao persicultor paulista, portando existe uma demanda muito grande por novas técnicas de manejo que possibilitem a melhoria da qualidade dos frutos. Várias estratégias vêm sendo pesquisadas em vários segmentos do processo produtivo , desde o plantio até a colheita, com o intuito de aumentar a produtividade e sobretudo melhorar a qualidade dos frutos. 
Dentro deste enfoque esta pesquisa teve como objetivos:

- Verificar a influência dos sistemas de podas e manutenção das folhas após a colheita nas reservas de carboidratos não estruturados em ramos e raízes do pessegueiro da cultivar Flordaprince.

- Verificar a produção dessas plantas e a qualidade dos frutos em função das reservas de carboidratos presentes nas raízes e ramos do pessegueiro.

-Verificar a eficiência do uso do regulador vegetal 2,4-DP (ácido diclofenoxipropiônico), em função das reservas de carboidratos existentes nas plantas, bem como seu possível efeito na qualidade dos frutos obtidos. 


\section{Revisão de Literatura}

Há indicações de que o pessegueiro, Prunus persica (L.) Batsch, seja uma espécie nativa da China, onde há mais de três milênios já se fazia referências à sua existência. Acredita-se que, da China, foi levado à Pérsia e, daí, distribuído a toda a Europa (Hedrick, 1916).

Segundo Sachs (1984) o pessegueiro é basicamente uma planta de clima temperado, por essa razão os mais importantes centros de produção comercial situam-se entre as latitudes $30^{\circ}$ e $45^{\circ} \mathrm{N}$ e S.

O pessegueiro foi introduzido na América do Norte pelos espanhóis, no início do século XVI, e, no Brasil, mais propriamente na cidade de São Vicente, a partir de 1532, pela expedição colonizadora de Martim Afonso de Sousa (Gould, 1923; Rigitano, 1945; Sachs, 1984).

\subsection{Características Fenológicas}

Quando deixado a se desenvolver naturalmente, o pessegueiro pode atingir mais de 6 metros de altura, e sobreviver por 50-60 anos, dependendo do material e das condições climatoedáficas. Nessas condições, possui um tronco principal com diâmetro ao redor de $40 \mathrm{~cm}$, de onde se originam ramos bem vigorosos, quatro a cinco, e que se afinam à medida que atingem a extremidade da copa (Barbosa, et al.,1989).

Os ramos podem ser classificados de acordo com a distribuição das gemas flor. Os ramos produtivos são classificados em mistos, brindilas, dardos e "ladrões". Os ramos mistos, os maisfreqüentes possuem comprimento variável entre 5 e $100 \mathrm{~cm}$; são portadores de gemas floríferas e vegetativas, terminando geralmente em um do último tipo. Nas brindilas, ramos finos e flexíveis com menos de $30 \mathrm{~cm}$ de comprimento, podem prevalecer gemas de flor. Seu ápice pode conter tanto uma gema florífera como uma 
vegetativa. Os dardos, ramos menores, com $5 \mathrm{~cm}$ de comprimento, apresentam gema apical vegetativa e numerosas gemas floríferas. Os "ladrões", ramos vigorosos, em geral inúteis para a produção, originam-se da base da planta ou de seu tronco e crescem em posição vertical; podem apresentar ramificação secundária, sempre com gemas vegetativas.(Barbosa, et al.,1989).

Ainda segundo esse autor, o sistema radicular do pessegueiro é, de início, pivotante e, passando a possuir numerosas raízes laterais, pouco profundas quando adulto, explora área aproximada à projeção de copa, seu ritmo de crescimento acompanha normalmente o da parte aérea, atingindo uma intensidade máxima no início do outono.

As folhas, duas a quatro por nó ou gema, são do tipo completas, oblongas, lanceoladas e com o pecíolos curtos. Suas dimensões são geralmente, 40-50 mm de largura por 140-180 mm de comprimento. As margens da lâmina foliar podem ser serrilhados, crenadas ou dentadas (Sachs, 1984).

O fruto do pessegueiro é do tipo drupa-carnoso típico, com fino pericarpo, mesocarpo carnoso e suculento (polpa) e endocarpo lenhoso (caroço). Em geral pode apresentar as seguintes aspectos: esférico, oblongo, elíptico e ovalado, às vezes com o ápice saliente. Sua epiderme, quando madura, pode apresentar as seguintes tonalidades: verde, creme ou amarela; de matiz róseo, vermelho ou vinho, variando de 0 até quase $100 \%$ com relação à superfície total do fruto. A polpa pode ser branca, creme, laranja, amarela e até avermelhada. O endocarpo (caroço), comumente ovoidal, pode ser preso, meio preso ou solto, e contém, no interior, uma amêndoa dicotiledônea do mesmo formato de seu invólucro; algumas cultivares possuem duas amêndoas em cerca de $20 \%$ dos caroços. O sabor da polpa pode apresentar graduações na faixa é doce-aciduladoforte ao simplesmente doce, com níveis de $\mathrm{pH}$ de grau Brix, de 3,5 a 5,0 e de 8,0 a 18,0 respectivamente. (Barbosa, et al., 989).

O fator climático mais importante na cultura do pessegueiro é a temperatura, pois essa afeta a distribuição das cultivares. É um fator muito difícil, ou praticamente impossível de se manejar, e por essa razão, é necessário escolher com critério o local de cultivo. Um abaixamento na temperatura pode ser alcançado ao se elevar a latitude, a 
altitude ou a continentalidade. O requerimento de horas de frio para a grande maioria das cultivares é de 600 a 1000 horas abaixo de $7,2^{\circ} \mathrm{C}$, para florescer e enfolhar normalmente, porém são conhecidas cultivares que necessitam de menos de 100 horas de frio (Herter et al., 1997).

Ainda segundo esse autor temperaturas de verão relativamente altas durante o dia e amenas no período noturno propiciam aumento no teor de açúcares e melhoria da coloração, uma vez que esses fatores influenciam a atividade fotossintética da planta. Segundo Sachs (1984), muitas cultivares tornam-se adstringentes quando cultivadas sob condições de verões frescos, o que geralmente ocorre em áreas de maior altitude.

\subsection{A fase vegetativa}

Comercialmente, o pessegueiro é propagado via vegetativa, através da enxertia de gemas adultas, para garantir produções precoces de frutos, uma vez que essas não revertem à juvenilidade. A propagação via semente é, em geral, utilizada pelo homem para a produção de porta-enxertos ou nos trabalhos de melhoramento genético da espécie, para a seleção dos genótipos de interesse.(Barbosa et al., 1989)

O estado inativo da planta, em que o crescimento vegetativo não é verificado é chamado de dormência (Janick, 1968; Westwood, 1978). Essa parada visível e temporária do crescimento está relacionada com estruturas das plantas que contêm meristemas (Lang et al., 1987). A dormência nas plantas é, pois, um mecanismo fisiológico adaptativo, especialmente desenvolvido para enfrentar as condições adversas do meio em que vivem: estresse hídrico, temperaturas baixas e nutrição deficiente, além de outras limitações de caráter endógeno.

Em virtude da existência de uma excessiva terminologia que conceitua a palavra dormência, foi proposta uma classificação definitiva para a caracterização das diversas manifestações desse comportamento fisiológico. Essa classificação se baseia na adição de três prefixos gregos à palavra dormência, a saber: eco, para e endo-. Então, de forma simples e uniformizada, os termos: ecodormência, paradormência e endodormência podem ser mundialmente empregados (Lang et al., 1987). Assim pode-se considerar que a ecodormência se refere a todos os casos de parada de crescimento regulado por fatores 
ambientes eventuais, como: temperaturas extremas, seca e excesso de umidade. A paradormência pode ser causada por certos sinais bioquímicos que, provenientes de regiões distintas da planta (meristema apical), afetam o crescimento de algumas de suas estruturas (gemas laterais, folhas). Pode ainda acontecer em resposta à variação do fotoperíodo. A endodormência ocorre em função de estímulos particulares ambientais (frio, fotoperíodo) ou endógenos (concentração hormonal), causando a parada de crescimento da planta.

O tipo de dormência que mais afeta o desenvolvimento do pessegueiro é a endodormência, verificada no outono e no inverno, principalmente em regiões temperadas e em latitudes mais Equatorias, pode ocorrer somente nas épocas mais frias ou secas do final do outono e início do inverno.De maneira geral, esse processo é desencadeado durante o encurtamento dos dias. Nesse período, as folhas maduras funcionam como receptoras de mensagens do espectro solar, possibilitando a ação do mecanismo de conversão dos pigmentos fitocromáticos. Esses fotorreceptores, motivados pelo estímulo externo (noites longas), são ativados e possibilitam que as células tenham a capacidade de sintetizar os hormônios inibidores específicos.(Barbosa et al. 1989).

Segundo Barbosa et al., 1989, entre as cultivares de pessegueiros existentes, cada um, em particular, demanda período de frio específico para iniciar o seu processo de quebra de endodormência. Mundialmente é adotado o parâmetro de número de horas de frio abaixo de $7,2^{\circ} \mathrm{C}$, para que ocorra a adequada brotação das plantas. Constitui, em última análise, o padrão da requisição de frio dos diversos materiais. Os pessegueiros das regiões temperadas podem exigir a devida quebra da endodormência entre 600 e 1.200 horas de frio abaixo de $7,2^{\circ} \mathrm{C}$. As plantas não se adaptam a regiões de pouco frio hibernal, pois, ao entrar em endodormência, dificilmente voltam ao estado vegetativo.

Em regiões de clima subtropical, em virtude de possuírem um inverno mais de clima ameno, o parâmetro de temperatura abaixo de $7,2^{\circ} \mathrm{C}$ vem sendo aos poucos substituído por outros. Em São Paulo, o parâmetro de $13{ }^{\circ} \mathrm{C}$ de temperatura pode ser adotado para algumas regiões de cultivo, pois as horas de frio acumuladas (abaixo de $7,2^{\circ} \mathrm{C}$ ) são praticamente desprezíveis. A região mais fria do Estado, Campos de Jordão, 
soma no inverno cerca de 200 horas de frio abaixo de $7,2^{\circ} \mathrm{C}$. A de Campinas acumula, em média, no inverno, cerca de 20 horas apenas de frio abaixo de $7,2^{\circ} \mathrm{C}$ (Pedro Júnior et al., 1979).

Em regiões tipicamente subtropicais, na prática persícola, é realizado no inverno um tratamento químico desfolhante e estimulador de brotação das gemas. Esse recurso se torna obrigatório, pois o outono e o inverno são ineficientes à senescência das folhas e à quebra da endodormência. O processo do desfolhamento químico parece causar certo estresse à planta, que, em decorrência, aumenta a taxa respiratória das células, culminando com a saída da endodormência (Shulman et al., 1983). Dessa maneira, o pessegueiro vegeta e frutifica normalmente, mesmo em condições não ideais.

Quando não sofre a interferência do persicultor, a planta permanece, em parte, com as velhas e inúteis folhas do ciclo anterior. Em decorrência, as gemas se desenvolvem sem sincronismo, prejudicando a necessária regularidade da floração e da frutificação e beneficiar a reciclagem de doenças.

O recurso da poda de ramos "endodormentes" do pessegueiro, logo após a aplicação dos produtos químicos, pode também auxiliar no desenvolvimento das gemas. A quebra da dormência imposta pelo meristema apical pode ser proporcionada através da eliminação da porção superior do ramo. A dominância apical é um fenômeno conhecido em muitas espécies vegetais. Aproximadamente após 30 dias do chamado tratamento de inverno, ocorre a plena floração do pessegueiro. Suas gemas vegetativas normalmente iniciam um crescimento visível pouco dias depois da abertura total das

flores. Em certas cultivares, entretanto, a exposição das gemas florais e vegetativas pode ocorrer concomitantemente, como nos híbridos mais aclimatados geneticamente. (Barbosa et al.,1989).

\subsection{A Fase reprodutiva}

A formação das flores passam pelas seguintes etapas: indução floral, iniciação floral, desenvolvimento floral e maturação dos gametas.

Segundo Nitsch (1957), o pessegueiro é considerado uma planta brevidiurna. Sua indução floral se inicia no verão, depois de uma etapa de intenso desenvolvimento 
vegetativo (Monet \& Bastard, 1970). A indução floral caracteriza-se por uma fase de mudanças metabólicas que induzem a diferenciação das gemas do estádio vegetativo à condição reprodutiva (Jraidi, 1983).

Segundo Tombesi, (1965) a gema é induzida à floração de modo definitivo quando a túnica do meristema, que na forma indiferenciada possui de três a quatro camadas de células, passa a ser constituída por uma ou duas, mudando da sua forma cônica, predominante, para a achatada.

Devido ao ao encurtamento dos dias, nessa fase, o sistema fitocromo presente nas folhas absorve a luz do vermelho, tornando-se fisiologicamente ativo. Dessa forma, há transmissão de estímulos às células, as quais produzem os hormônios específicos para a indução e diferenciação floral. O responsável pelo estímulo de floração foi considerado como um hormônio, o "florígeno", embora este ainda não tenha sido completamente isolado ou identificado. O controle da ativação de um complexo de genes, os quais, funcionalmente ativos, condicionam as primeiras modificações do meristema, parece ser feito pelos fitocromos. Em decorrência, a atividade do anel inicial é anulada, diminuindo, assim, conseqüentemente, a produção de folhas (Searle, 1965; Kendrick \& Frank-land, 1981).

Todavia a indução floral não afeta todas as gemas; algumas conservam as suas características vegetativas, o que garante a perenidade da árvore e, assim, a perpetuação da espécie.

A iniciação floral é caracterizada por alterações morfológicas do meristema, que se modifica irreversivelmente em flor. Essas modificações ocorrem no domo do meristema, que restringi o desenvolvimento vegetativo e corresponde ao período de inibição da própria formação dos primórdios foliares. Em seguida, o meristema apical passa por intensa atividade mitótica, e o domo apical aumenta consideravelmente. No Brasil, essa diferenciação não é bem conhecida, mas por analogia deve ocorrer entre dezembro e janeiro. Em seguida, o domo apical forma o receptáculo da flor, diferenciando, sucessivamente, as sépalas, as pétalas, os estames e o pistilo (Barbosa et al., 1989). 
A interrupção da endodormência, promovendo a retomada do crescimento dos órgãos florais e a maturação das células reprodutivas pela meiose, culminando com a abertura da flor caracteriza o processo de desenvolvimento floral.

De maneira geral, a florada do pessegueiro, em plantas individuais, pode persistir de uma a duas semanas, dependendo das cultivares, dos fatores internos e das condições ambientais. Em São Paulo, a floração ocorre entre junho e julho, e, à exceção das regiões mais frias, as quedas de temperatura normalmente não causam danos sérios às flores e aos frutos jovens.

A produção e germinação do pólen do pessegueiro parece não ser estável ao longo dos anos. Bassols (1980) relatou algumas mudanças ocorridas de um ano por outro, em cultivares gaúchos, como: Capdeboscq, Cerrito, Cheripa e Coral.

Segundo Westwood, (1978) o conhecimento do processo de frutificação de uma espécie, bem como dos demais fatores inter-relacionados, é extremamente importante ao discernimento de algumas práticas culturais como: poda, raleio de frutos, uso de fertilizantes e de reguladores de crescimento. As projeções da colheita, bem como do tamanho final dos frutos, estão fortemente relacionadas com as características de frutificação da espécie.

Entretanto, após a polinização da flor e a fertilização da oosfera, muitos outros fatores podem influenciar a taxa de pegamento, o crescimento, o tamanho (peso) e a qualidade final dos frutos.

As relações hormonais são, em grande parte, diretamente responsáveis pelo sucesso da frutificação. A persistência do fruto à planta depende do balanço exato entre as auxinas, giberelinas, citocininas e etileno. Cada espécie, em particular, requer uma combinação ou uma taxa hormonal específica para sua adequada frutificação. Os sítios de síntese desses hormônios encontram-se no próprio fruto em desenvolvimento, o que determina as taxas de pegamento e de crescimento. Os fatores externos como temperatura, água, umidade, podem afetar significativamente a frutificação da planta (Westwood, 1978).

Segundo Greulach, (1973) as auxinas oriundas do tubo polínico e das proximidades do tecido do pistilo parecem ser primeiramente suficientes para o 
apropriado pegamento do fruto e desenvolvimento do embrião da maioria das espécies. No caso específico do pessegueiro, o crescimento e o desenvolvimento do fruto e da semente estão fortemente relacionados com a periodicidade de síntese da auxina (AIA:ácido indolacético). Tal variação periódica (cíclica) possibilita uma relação de causa-efeito bastante evidente em algumas fases do período de sua frutificação.

Segundo Powell \% Pratti, (1966); Crane, (1969); Lilien-Kipnis \& Lavee, (1971), o desenvolvimento dos frutos do pessegueiro segue uma curva sigmoidal dupla, com o estádio I caracterizado pela proliferação celular, o estádio II, em que ocorre a lignificação do endocarpo ou endurecimento do caroço e o estádio III, de crescimento celular.

O ciclo de maturação do pêssego pode variar consideravelmente em função das características genéticas de cada cultivar. Existem cultivares com ciclos da florada à maturação desde 60 até acima de 200 dias. A duração dos estádios I e II pode diferir apenas de cinco a dez dias para essas cultivares com diferentes ciclos de maturação. Porém a grande variação é verificada no estádio III, durante o crescimento final da polpa (Barbosa, 1989).

O estádio III de crescimento dos frutos de pêssego se caracteriza por altas necessidades em carboidratos, que se acumulam, e uma diminuição da taxa fotossintética do fruto, o que explica a competição entre desenvolvimento vegetativo e desenvolvimento reprodutivo durante essa fase (Agusti et al, 1997). Todavia, após se proceder a colheita a demanda de carboidratos é reduzida consideravelmente, especialmente se o novo desenvolvimento vegetativo tenha cessado. Portanto, o total de carboidratos armazenados necessário para o ciclo de produção seguinte dependerá da duração da folhagem no período da colheita, até a caída natural das folhas (Flore, 1994).

A maturação do fruto maduro é caracterizada por mudanças na coloração, aumento do teor de açúcares, diminuição da acidez, intensificação no aroma e diminuição da firmeza da polpa, que a torna mais suculenta. Essas mudanças físicas, bioquímicas e fisiológicas são facilmente perceptíveis.

Neste contexto, buscam-se métodos para melhorar a qualidade dos frutos mediante a utilização de porta-enxertos ananicantes (Campos-Dall'orto et al., 1992, 
Nakamura et al., 1999), anelamento de troncos e ramos (North et al., 1988; De Villiers et al., 1990), métodos de podas e condução (Loreti \& Pisani, 1992, Scarpare Filho et al., 1999), aplicação de reguladores vegetais (Agusti et al., 1996, Blanco, 1990), utilização de interenxertos ou filtros (Reichard, 1992 e 1995, Scarpare Filho, et al., 2000b) e técnicas de raleio de frutos (Seno, 1971; Raseira et al., 1998, Scarpare Filho, et al., 2000a).

\subsection{Poda}

Devido a sua biologia , o pessegueiro constitui uma espécie em que a poda anual de frutificação se torna obrigatória. A frutificação só ocorre em ramos do ano anterior. Após a frutificação, o ramo perde sua função, e se não for podado, será apenas uma ponte entre a raiz e a parte superior da copa. Nessa situação a planta frutifica cada vez mais distante opondo, com isso dificuldades à nutrição (Simão, 1998).

Segundo Fuertes \& Hernández, (1995), a poda é uma prática de cultivo que consiste em conduzir as plantas, modificando seu desenvolvimento natural, a fim de equilibrar sua capacidade vegetativa e produtiva, e se obter a maior produção com frutos de alta qualidade, distribuías de forma uniforme pela totalidade da copa. Também tem por finalidade obter plantas de tamanho adequado para executar de forma funcional os trabalhos de condução.

No pessegueiro, as gemas floríferas são produzidas nos ramos que crescem na estação anterior. Logo, é fundamental que as árvores sejam forçadas a crescer anualmente. Isso justifica o fato de que a poda é um tratamento cultural importante e imprescindível na altura do pessegueiro. Contudo, Raseira et al, (1998), afirmam que não há regra invariável para a poda, sendo necessário, antes de tudo, bom senso e conhecimento dos seus princípios e finalidades, e principalmente o conhecimento do hábito de frutificação da planta. Esse mesmo autor afirma que a época ideal para se fazer a poda do pessegueiro é durante o período de repouso. Não deve ser muito cedo, a fim de se evitar o estímulo a brotação precoce, nem muito tarde, para prevenir perda de reservas, eliminadas pela poda. Se acaso a poda for feita muito cedo, reduz-se o número de frutos por planta, embora eles se apresentem com um bom tamanho. Já plantas 
podadas após o período de dormência, com frutos em formação, produzem grande quantidade de frutos pequenos e tem seu desenvolvimento vegetativo reduzido.

Segundo Faust (1989), a poda diminui efetivamente, o tamanho da árvores, alterando conseqüentemente seu dossel, e induzindo, assim, variação em suas reservas de carboidratos. $\mathrm{O}$ autor constatou que o metabolismo de carboidratos, especialmente durante o inicio de crescimento, foi distinto em plantas podadas e não podadas. Além disso, a época em que é realizada a poda interfere de maneira decisiva no crescimento das plantas. $\mathrm{O}$ autor considera que o armazenamento de carboidratos é necessário para sustentar o desenvolvimento das plantas em períodos de estresse, durante a dormência, e muito importante durante a iniciação de crescimento e frutificação na primavera. Essas reservas de carboidratos não estruturados, em frutos de caroço, mudam quantitativa e qualitativamente durante os estádios de crescimento dos frutos, e nas plantas durante as estações de crescimento. Isso também foi verificado por Borba, 2002, segundo o autor os teores de carboidratos não estruturados mudam durante o ciclo da planta. Além, o autor ainda prega que os tipos de podas interferem nos teores de carboidratos no sistema radicular, todavia não houve interferência nos teores de carboidratos na copa.

É sabido que quando a poda é realizada em plantas dormentes, geralmente observa-se maior vigor às plantas, quando comparadas às plantas podadas no verão, que têm seu vigor diminuído. Diversos tipos de podas de verão podem ser utilizados (Marini, 1985; Barbosa et al, 1999). A poda de renovação é bastante utilizada no Estado de São Paulo, e consiste na poda, após a colheita dos frutos, de todos os ramos da planta, independentemente se produziram ou não. Em nossas condições, posteriormente à poda, ocorre a brotação, iniciando, assim, o crescimento vegetativo e a diferenciação das gemas para a safra seguinte. Ao se comparar os dois tipos de podas: a tradicional, realizada no final da dormência, e a de renovação, Nienow (1997), verificou que a poda de renovação realizada no final da primavera, embora tenha retardado o desfolhamento e evitado o florescimento no final do verão, afetou a produtividade do pomar. Entretanto Marini (1985), estudando podas em plantas dormentes e podas de verão, não constatou nenhuma diferença na produção, tamanho de frutos e época de maturação, nos diferentes tratamentos estudados. 
De qualquer forma, a poda na cultura do pessegueiro é uma técnica de manejo já consagrada e tem como um dos objetivos principais manter o equilíbrio entre o desenvolvimento vegetativo e reprodutivo, evitando assim a alternância de safras, e reduzindo a mão-de-obra necessária para se realizar o raleio (Callesen \& Wagnmakers, 1989; Olien, 1992; Dejong et al., 1992; Campo Dall'orto et al., 1991).

Entretanto alguns fatores climáticos, como geadas, chuvas de granizo, vendavais entre outros, e técnicas culturais, como, poda, raleio de frutos, utilização de fitoreguladores, tratamentos fitossanitários, entre outras, podem afetar as reservas das plantas. Segundo Lloyd, Firth, (1989); Agusti, et al ,(1997); Raseira et al, (1998), a desfolhação precoce das plantas no verão e outono pode influenciar na produtividade dos pomares, devido a redução de reservas de carboidratos.

Segundo Bleicher \& Tanaka (1982), a diminuição da área foliar, devido a queda precoce das folhas, comum nas regiões subtropicais, pode provocar uma segunda floração no outono, trazendo prejuízos consideráveis à planta, pois essa florada não será aproveitada e na planta ocorre um dispêndio de energia para emiti-la.

Os nutrientes disponíveis na planta se movem preferencialmente até os frutos em desenvolvimento às expensas de outros órgãos da planta (Agusti et al., 1997). Essa característica dos frutos de atuar como drenos fisiológicos deixa implícito o fenômeno de competência ativa, entre os frutos em desenvolvimento e folhas por nutrientes disponíveis na planta.

O vigor das plantas, a produção e a qualidade dos frutos colhidos são função das características genéticas, das condições ambientais e das reservas de carboidratos, portanto sofrem forte influência das técnicas de manejo adotadas.

\subsection{Regulador Vegetal}

Hormônio vegetal é um composto orgânico, não nutriente, de ocorrência natural, produzido na planta, o qual a baixa concentração promove, inibe ou modifica processos morfológicos e fisiológicos do vegetal. Os reguladores vegetais são substâncias sintetizadas, que aplicadas exogenamente, possuem ações similares aos hormônios (Castro \& Vieira, 2001). . 
Com o propósito de se obter frutos com características mais adequadas àquelas exigidas pelo mercado tem-se ainda, lançado mão de muitas técnicas, dentre as quais pode-se salientar o uso de reguladores de crescimento vegetal. O caminho se abriu em 1934, quando químicos holandeses identificaram o ácido 3-indolacético (auxina), como substância natural de crescimento (Luckwill, 1994).

Segundo Castro \& Fachinello (1995) embora as substâncias de crescimento endógenas normalmente controlam o crescimento da planta, modificações do desenvolvimento podem ser produzidas por aplicações exógenas de substâncias de crescimento, algumas das quais pode produzir efeitos benéficos ao homem.

Segundo Luckwill (1994), os reguladores vegetais induzem muitas vezes, efeitos nas plantas que são idênticos àqueles produzidos pela ação de um gene, o que poderia argumentar-se que seria melhor esforçar-se em melhorar os cultivos mediante o melhoramento genético que mediante a aplicação de reguladores vegetais, cujos efeitos são transitórios. Contudo, ainda que o melhoramento genético seja um objetivo desejável a longo prazo, em poucas ocasiões oferece soluções imediatas aos agricultores, em especial os fruticultores.

Em espécies frutíferas de caroço as aplicações de reguladores vegetais estão restritas a um número de opções menor que em frutíferas de semente (maçã, uva e citros). Entre as possíveis causas desta menor utilização está a alta variação na reposta à aplicação destes compostos, assim como a enorme quantidade de variedades cultivadas, cada uma delas respondendo de forma distinta a um mesmo tratamento, o que complica a generalização dessas possíveis aplicações (Blanco, 1990).

Segundo Marodin et al., 2000, a época de aplicação das auxinas visando estimular o desenvolvimento do fruto em espécies de caroço não é um fator definitivo para a determinação da resposta. Esse conceito entretanto deve ser matizado, uma vez que todos os experimentos realizados foram desenvolvidos sem exceção, após um raleio manual e a redução drástica da competição entre frutos, que é obtida com esta prática cultural, é muito mais eficaz na determinação do tamanho final do fruto que qualquer outra coisa. É usual a utilização das auxinas durante a fase em que o endocarpo inicia 
seu endurecimento, pois reflete um estado de desenvolvimento do fruto facilmente identificável.

\subsection{Auxinas}

Segundo Hopkins (1995), as auxinas foram o primeiro grupo de hormônio vegetal a serem descobertos. Elas são caracterizadas pela capacidade de estimular o elongamento celular em caules cortados e seções coleoptiles, mas também influencia várias outras respostas do desenvolvimento, incluindo iniciação radicular, diferenciação vascular, tropismo e o desenvolvimento de gemas axilares, flores e frutos.

As auxinas são hormônios vegetais produzidos principalmente nas regiões apicais que, transportados para outros locais da planta, participam do seu crescimento e diferenciação. Darwin, em 1880, foi o precursor da descoberta das auxinas, quando estudou o fototropismo em coleóptiles de alpiste (Phalaris canariensis).Somente em 1926 a auxina, responsável pelo fototropismo, foi isolada por Went dos ápices de coleóptiles de aveia colocados sobre pequenos cubos de ágar. Após algumas horas esses cubos adquiriram a propriedade de estimular a curvatura de coleóptiles decapitados quando colocados unilateralmente, no escuro. Went também observou que a curvatura desses coleóptiles era proporcional à quantidade de auxina presente nos cubos de ágar, estabelecendo um teste biológico de ampla utilização. A primeira auxina isolada foi o ácido indolacético (AIA), a mais importante que ocorre nas plantas, responsável por numerosos processos biológicos em vegetais.Uma determinada concentração de auxina, capaz de promover o crescimento do caule de uma planta, poderá inibir o crescimento da raiz dessa mesma planta, requerendo os diferentes órgãos vegetais, diferentes concentrações de auxina para sua máxima alongação. Concentrações acima de um nível ótimo podem induzir, na planta, a síntese de outro hormônio vegetal, o etileno. $\mathrm{O}$ transporte das auxinas naturais é do tipo polar, em que o movimento ocorre da região apical para a basal. A velocidade de transporte é da ordem de 5 a $15 \mathrm{~mm} / \mathrm{hora}$, sob 20 a $25^{\circ} \mathrm{C}$. (Castro \& Fachinello, 1995)

Muitas evidências sugerem que a auxina está envolvida na regulação do desenvolvimento do fruto. A auxina é produzida pela pólen, no endosperma e no 
embrião de sementes em desenvolvimento, e o estímulo inicial do crescimento do fruto pode ser resultado da polinização. Depois da fertilização, o crescimento do fruto pode depender da auxina produzida nas sementes em desenvolvimento. O endosperma pode contribuir com auxina no primeiro estágio do crescimento do fruto, e o desenvolvimento do embrião pode assumir como a principal fonte de auxina durante os outros estágios. Entretanto, outros hormônios vegetais estão envolvidos no crescimento do fruto. Por exemplo, o etileno é um conhecido influenciador no desenvolvimento do fruto, e alguns efeitos da auxina na frutificação pode ser a promoção da síntese de etileno (Taiz \& Zeiger, 1998)

Segundo Hopkins (1995), as auxinas podem também ser utilizadas para controlar a abscisão de frutos. Em função da época e nível de aplicação, a auxina pode causar ou prevenir a queda prematura de frutos. A intensificação precoce da queda de frutos causada pela auxina logo após a fase de "fixação de frutos", é um método de raleio químico, com o objetivo de aumentar o tamanho dos frutos remanescentes na árvore. Aplicada mais tarde, a auxina atrasa a abscisão, prevenindo a queda prematura de frutos.

$\mathrm{O}$ alongamento da parede celular é a resposta inicial dos tecidos vegetais às auxinas. Esta primeira fase da resposta é extremamente rápida e exclui a síntese de novas proteínas. A segunda fase do alongamento da parede celular exige a síntese de proteínas (enzimas). A parede celular é constituída por microfibrilas de celulose unidas por polissacarídeos complexos. Apesar de todos os processos responsáveis pela alongação celular por ação auxínica não terem sido ainda esclarecidos, alguns deles podem ser apontados a partir de evidências experimentais (Castro \& Fachinello 1995).

A rápida resposta em alongamento da parede celular parece estar relacionada com a acidificação. A auxina poderia estimular uma bomba de prótons que promoveria a secreção de íons hidrogênio em um compartimento da parede celular causando acidificação. A secreção de prótons poderia ser compensada por um movimento de cátions para o protoplasma. A acidificação promoveria a ativação de enzimas preexistentes causadoras do afrouxamento da parede celular. Isso possibilitaria uma expansão celular por efeito do potencial de pressão do interior da célula. A síntese de ácidos nucléicos e de proteínas, sob efeito de auxinas, mostra-se importante para o 
mecanismo de expansão da parede celular. Uma reserva de glicose e xilose, além de outros carboidratos, deve estar presente no sistema que dará origem ao material necessário para o processo de alongação. Uma dessas enzimas, sob efeito de auxinas, poderia ter a propriedade de romper e refazer, após um deslize, ligações glicosídicas entre polissacarídeos da parede celular, causando afrouxamento da parede e alongação celular por efeito do potencial de pressão do interior da célula. Outra enzima seria a bglucam síntese que se formaria no aparato de Golgi por ação da auxina, assim como um xiloglucam, sendo ambos os produtos transportados para a parede celular através das vesículas de Golgi, formadas nas regiões mais maduras do aparato de Golgi. O xiloglucam seria incorporado na parede celular por ação da b-glucam sintetase também foi verificada no retículo endoplasmático, de onde seria transportada para a parede celular, podendo promover a incorporação de celulose originária do protoplasma. (Castro \& Fachinello 1995).

Além disso, as moléculas de hormônio $(\mathrm{H})$ induzem a abertura de canais de $\mathrm{Ca} 2+$ na membrana plasmática, o cálcio é transportado para reservatórios internos (no vacúolo ou retículo endoplasmático) para a manutenção da homeostase do $\mathrm{Ca} 2+$ no citosol. $\mathrm{O}$ aumento da concentração de $\mathrm{Ca} 2+$ no vacúolo causa a liberação de $\mathrm{H}+$, o qual diminui o $\mathrm{pH}$ citosólico e induz a atividade do transportador de H+ (ATPase), na membrana plasmática. $\mathrm{O}$ co-transporte de $\mathrm{H}+/ \mathrm{K}+$, com o influxo de ânions orgânicos, reduz o potencial osmótico do vacúolo e promove a entrada de água, causando turgescência que leva a alongação celular. Paralelamente, a ligação da auxina ao receptor protéico da membrana, desencadeia uma série de eventos que amplificam sua atividade, levando a produção de fosfoinositídeos (IP2, IP3). Esses mensageiros secundários promovem liberação de $\mathrm{Ca} 2+$ do retículo endoplasmático, levando à formação do complexo cálciocalmodulina (CaM). CaM induz ativação da proteína quinase, resultando na fosforilação de um fator protéico capaz de combinar-se com a auxina. O complexo auxina-Pproteína, assim formado, estimula a transcrição de seqüências de RNA responsáveis pela produção de precursores de b-glucam sintetase, envolvida na síntese de componentes da parede celular (Castro \& Fachinello, 1995). 


\section{7 Ácido diclofenoxipropiônico (2,4DP)}

Segundo Blanco (1990); Agusti (1994); Agusti (1996), a aplicação de auxinas como 2,4-D, o 2,4,5T e o 2,4,5TP, realizadas logo após o início de fase II (endurecimento do endocarpo), reduz substancialmente a queda de frutos, produz aumento no peso médio e adianta a maturação dos frutos.

A aplicação de $25 \mathrm{mg} .1^{-1}$ de $2 \mathrm{~m}, 4$ DP é considerada suficiente para a obtenção de resultados ótimos em frutas de caroço. Incrementos entre 5\% e 10\% no diâmetro médio dos frutos foram obtidos em todas as espécies e cultivares estudadas por Agusti (1997).

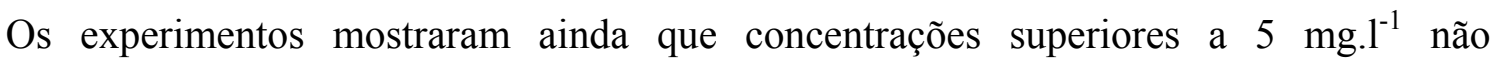
conseguiram melhorar as respostas.

Após a aplicação de 2,4DP (ácido diclofenoxipropiônico) em pessegueiro, na fase de endurecimento do endocarpo, verificou-se adiantamento de colheita, aumento do tamanho do fruto, aumento de produtividade e melhora na coloração (Benito et al, 1995).

Segundo Agusti (1997) as plantas tratadas com $25 \mathrm{mg} . \mathrm{l}^{-1}$ de 2,4 DP tiveram o diâmetro médio de seus frutos aumentado, no momento da colheita entre 2 e $4 \mathrm{~mm}$, comparativamente às plantas controle. Isso supõe aumentos da ordem de 5 a 25 gramas por fruto em seu peso médio.

Em trabalho com a cultivar "Springlady", Agusti et al. (1995) constatou que a aplicação de $25 \mathrm{mg} / 1$ de 2,4 DP, entre 25 e 40 dias antes da maturação dos frutos não proporcionou diferenças significativas no diâmetro final médio dos frutos. Constataram também que a concentração que proporcionou os melhores resultados de tamanho médio dos frutos, tanto para esta variedade de pêssego, como para a cultivar de nectarina "Maybelle", foi a de $25 \mathrm{mg} / 1$ de 2,4 DP. O efeito desta auxina foi detectado após 15 dias da aplicação, intensificando-se entre 18 e 20 dias. A aplicação de $25 \mathrm{mg} / 1$ de 2,4 DP proporcionou uma melhor coloração dos frutos em todas as variedades testadas, devido ao estímulo promovido ao desenvolvimento dos frutos (Juan et al., 1997).

Souza, et al.,(1998) constataram que o uso de 2,4 DP em pessegueiro da cultivar "Chiripá", com 6 anos de idade, previamente submetidas ao raleio manual de frutos, proporcionou um aumento do diâmetro e a antecipação da colheita dos frutos. 
Estudando a incisão anelar e o anelamento de ramos, Agusti et al. (1998), constataram que não houve diferenças na qualidade dos frutos entre as práticas, mas a incisão anelar apresentou vantagens, pela maior agilidade de mão de obra, diminuindo os custos de produção, além de provocar menores danos às plantas.

Segundo Vieira (20030, ao uso de regulador vegetal 2,4-DP e o anelamento de ramos, na cultivar de meia estação Biuti, não se mostrou eficaz quanto a antecipação da colheita. A prática do anelamento de ramos, associada ou não a diferentes concentrações de 2,4-DP, não alterou o $\mathrm{pH}$, a acidez total, nem o teor de sólidos solúveis totais do fruto. Todavia, estes apresentaram a coloração da casca bastante intensificada em relação aos frutos de plantas não tratadas.

\subsection{Considerações fitotécnicas e ecofisiológicas da persicultura em alta densidade populacional}

A compactação extrema de pomares de pessegueiros pode ser caracterizada pelos seguintes conceitos fitotécnicos: a) o espaçamento mínimo entre as plantas e as linhas e deverá ser aquele agronomicamente mais suportável pela cultivar, sem que, no entanto, haja competição prejudicial entre os indivíduos; b) as mudas poderão ser formadas no próprio local de cultivo definitivo; c) a altura das plantas deverá ser de dois metros e meio, porte este próximo do ideal para uma boa produção de frutos; d) a poda drástica anual constitui a maneira mais prática de manter as árvores sempre pequenas; e) as operações no pomar podem ser total ou parcialmente mecanizadas, reduzindo o trabalho manual; f) as produções anuais de frutos resultam de uma copa totalmente renovada; g) a luminosidade incidente no interior do pomar é muito similar em todos os anos, devido ao regime de desenvolvimento da copa; h) o emprego de pesticidas e adubos tornam-se mais eficientes, e i) o sombreamento causado pelas copas das plantas ajuda a manter a umidade do solo e a diminuir a presença de ervas invasoras (Campo Dall'orto et al., 1984a, b; Erez, 1985).

No entanto, para se adotar a maior densidade de plantio, é fundamental um conhecimento prévio do nível de competição biológica que o sistema adotado pode proporcionar às plantas. Sem um estudo preliminar detalhado da época de poda, da 
necessidade individual em relação a luz, água, nutrientes e outros fatores, o pomar pode não atingir o grau de uniformidade desejável e, assim, desvirtuar-se do objetivo principal, que é o aumento da produção por unidade de área.

Os fatores que implicam na competição das plantas podem ser eliminados na escolha da cultivar copa ou porta-enxerto (características vegetativas e reprodutivas), no delineamento do pomar (clima e solo predominantes, espaçamento e condução) e nos tratos culturais (poda, irrigação, nutrição, fitossanidade, capina e outros (Barbosa et al., 1989).

Para o aperfeiçoamento da técnica de condução dos pomares em ultra-alta densidade de plantio, pesquisas complementares devem ainda merecer especial atenção. Dentre essas, as prioritárias acham-se ligadas às áreas de melhoramento genético, de fisiologia, de propagação e de mecanização (Barbosa, et al. 1989).

O comportamento de 29 seleções de pessegueiros em ultra-alta densidade de plantio, com poda drástica anual de renovação de copa. Os espaçamentos adotados, de $3,0 \times 0,5 \times 0,5 \mathrm{~m}(0,875 \mathrm{~m} 2 /$ planta $)$ em fileiras duplas, e de $3,0 \times 0,5 \mathrm{~m}(1,500 \mathrm{~m} 2 /$ planta $)$ em fileiras simples, corresponderam às densidades de 11.428 e 6.666 plantas por hectare respectivamente. Nessas densidades populacionais, não se evidenciaram nitidamente os efeitos negativos de competição biológica entre os diferentes indivíduos. Esse fato foi comprovado pelas altas produções das seleções pesquisadas. Das cultivares experimentadas, elegeram-se, a princípio, cerca de dez mais promissoras, que se destacaram pela precocidade, alta produtividade de frutos e razoável desenvolvimento vegetativo: 'Flordaprince', 'Maravilha', 'Jóia-1', 'Jóia-2', 'Jóia-4', 'Dourado-1', 'Ouromel-3', 'Doçura-2', IAC 4974-10. Conforme os resultados experimentais, as suas produções variaram na faixa de 25 a 35t/ha, quando em fileiras duplas, e de 20 a 30t/ha, em fileiras simples. As demais seleções foram consideradas a princípio não adequadas ao sistema de poda drástica anual, pois com ciclo de maturação precoce-mediana, não conseguiram recuperar, em tempo hábil, nova copa fisiologicamente madura. A produção média, obtida no primeiro ano de frutificação, foi equivalente à de um pomar com idade de seis a oito anos de idade, conduzido convencionalmente no espaçamento tradicional (7 x 5m) (Campo Dall'orto et al, 1984a). 
Mesmo com os atuais resultados promissores obtidos nas condições climáticas subtropicais paulistas, acredita-se que com a seleção de novas cultivares mais precoces (ciclos de 70 a 80 dias da florada à maturação), os tratos culturais sejam ainda mais facilitados e o sistema definitivamente viabilizado. Além da maior precocidade, as cultivares devem apresentar rusticidade em seus hábitos vegetativos e reprodutivos, assim como completa adaptação ao clima de características subtropical-tropicais.

A arquitetura da planta nesse sistema constitui outro fator relevante na seleção de genótipos; assim, quanto menor o ângulo dos ramos vegetativos, maior poderá ser o aproveitamento de energia radiante disponível (Ferraz, 1985). O auto-sombreamento completo da parte inferior da copa não é interessante para o pessegueiro, a exemplo do que ocorre na maioria dos cultivos perenes. Apesar das adaptações fotocromáticas das folhas sombreadas (Magalhães, 1979), o pessegueiro se enfraquece, diminuindo o número de ramos internos de produção. Dessa forma, a maioria dos órgãos intracopa torna-se bastante dependente dos fotossintetizados das partes mais externas da planta. Outras características para melhor adaptação ao sistema devem ser também consideradas: maior capacidade e eficiência na absorção e aproveitamento de água e nutrientes do solo, e maior resistência varietal a pragas e doenças

Em relação ao efeito negativo do auto-sombreamento. Tombesi \& Belleggia (1986) relataram que pessegueiros 'Flavorcrest', cultivados no espaçamento de 4,5 x 3,5m (635 plantas/hectare), sob a condução de líder central, apresentaram comportamento distinto quando submetidos ou não a podas de verão. Nas plantas assim conduzidas, dotadas de copas menos compactadas, houve maior diferenciação floral e os frutos produzidos foram maiores e de melhor colorido e sabor. As copas adensadas mostraram-se bastante ineficientes e irregulares na formação de gemas de flores, em razão da deficiente penetração de luz.

O sistema de pessegais compactos, com conseqüente emprego da poda drástica para renovação da copa, parece ter sérias limitações em muitas regiões do globo, onde o outono e o inverno são estações impeditivas do desenvolvimento vegetativo. Um experimento conduzido em área central de Oklahoma, EUA, mostrou que plantas de 'Redhaven' adensadas diferenciaram um mínimo de gemas florais, aos insignificantes 
níveis de 5 a 10\%. Além desse fato, essas gemas em desenvolvimento apresentaram atraso de aproximadamente dois meses em relação à sua época normal de diferenciação. Essa mesma cultivar, quando mantido em densidade e tratos culturais convencionais, produziu normalmente elevado número de flores e frutos por ramo (Warriner et al., 1985).

O excessivo vigor vegetativo dos pessegueiros, submetidos à poda drástica, constitui outro fator que pode dificultar, em certos casos, o estabelecimento de pomares em ultra-alta densidade. Esse crescimento vigoroso dos ramos pode acarretar uma competição intensa e indesejável entre os frutos por água, carboidratos, minerais e reguladores de crescimento, o que conseqüentemente causa uma produção de baixa qualidade. Para solucionar esse problema, pode-se lançar mão de porta-enxertos ananicantes ou mesmo de produtos químicos, como certos reguladores de crescimento, que bloqueiam de certo modo a síntese do ácido giberélico (GA3) e do ácido indolacético (AIA). Esses dois métodos paliativos fazem com que as plantas fiquem menores e mais compactas e, assim, mais compatíveis ao maior adensamento (Hansche et al., 1979; Erez, 1986).

Com o aumento da densidade de plantio e a conseqüente mudança nas dimensões da planta, não devem ser desprezados os efeitos do regime e da quantidade de luz incidente no pessegal (Jackson, 1980; Avidan \& Erez, 1986). Como a quantidade de fotossintetizados obtidos pela planta é influenciada, em última análise, pela intensidade e qualidade da luz incidente (Hall \& Rao, 1980), a disposição, a direção de plantio e o manejo da copa devem constituir fundamentos essenciais à implantação da ultra-alta densidade.

Para adequada interceptação e distribuição da radiação luminosa pela copa, ela deve estar livremente exposta a várias direções. Ao que parece, o sentido de plantio Norte-Sul é o que proporciona o melhor padrão de interceptação da luz. Sob essa orientação, são obtidas maiores produções e frutos de melhor qualidade. Para determinadas densidades, as plantas se desenvolvem melhor quando dispostas em renque duplo ou em triangulação (Jackson, 1980), pela sua melhor disposição no espaço útil. 
As práticas culturais, como certas podas de verão (Miller, 1987), irrigação controlada (Chalmers et al., 1981) e mesmo o desfolhamento parcial das plantas, normalmente tornam a copa bem mais eficiente na utilização da luz, durante o período de maior compactação foliar.

\subsection{Carboidratos}

A água é a principal substância translocada via floema, representando $98 \%$ do total, sendo que os $2 \%$ restantes compõem-se de solutos orgânicos e não orgânicos. Destes solutos, 98\% são açucares e 2\% outras substâncias (compostos nitrogenados, ácidos orgânicos, aminoácidos, ATP, reguladores de crescimento, etc.)

Os solutos orgânicos são compostos de sacarose (99\%) e verbascose, rafinose, estaquiose, etc.

As reservas de carboidratos não estruturados, em frutos de caroços, mudam qualitativa e quantitativamente durante os estádios de crescimento dos frutos, e nas plantas durante as estações de crescimento.

De forma resumida, ao incidir a luz nas folhas, ocorre a fotossíntese, tendo como produto a hexose (podendo ser glucose ou frutose). Em pH básico ou neutro, com a ação da enzima amilofosforilase, esta hexose acumula-se, nas forma de amido. Já em pH básico, com a ação da invertase, as hexoses transformam-se em sacarose, que são transportadas via floema para as regiões de dreno, podendo ser estas regiões ativas, como desenvolvimento de ramos, flores, frutos, etc., ou em regiões de armazenamento, tecidos de reserva- nas raízes ou ramos.(Castro, 1985).

O amido e a sacarose são os principais carboidratos formados na fotossíntese. o amido é imóvel, sendo sintetizado nos cloroplastos dos órgãos fotossintetizantes, e nos amiloplastos em órgãos não fotossintetizantes.

A sacarose é móvel e é sintetizada no citosol das células e descarregada no floema. A sacarose, por ser móvel, é o principal substrato para a respiração, que mantém o vegetal vivo e ativo.

Uma vez translocada para locais não fotossintetizantes, como as raízes, a sacarose é rapidamente convertida em frutose e glicose por enzimas invertases. 
De uma forma geral, os açucares solúveis que proporcionam a energia necessária para o metabolismo da planta, são derivados da hidrólise do amido dos tecidos de reserva por ação de enzimas hidroliticas.

O armazenamento de carboidratos é necessário para sustentar o desenvolvimento das plantas em períodos de estresse, durante a dormência, e durante a iniciação de crescimento e frutificação.

Nas raízes, os carboidratos mais simples formados podem ser utilizados de 3 formas:

a) na respiração para a formação de ATP e outros compostos importantes. A respiração é comumente expressa em termos de oxidação de um açúcar de 6 carbonos;

$\mathrm{C}_{6} \mathrm{H}_{12} \mathrm{O}_{6}+6 \mathrm{O}_{2}+6 \mathrm{H}_{2} \mathrm{O} \rightarrow 6 \mathrm{CO}_{2}+12 \mathrm{H}_{2} \mathrm{O}$

b) ser armazenado nos vacúolos para posterior uso na respiração;

c) a glicose pode ser convertida em amido, servindo como reserva para uso em situações onde há pouca atividade fotossintética da parte aérea.

O armazenamento de carboidratos é necessário para sustentar o desenvolvimento das plnatas em períodos de estresse, durante a dormência, e muito importante durante a iniciação de crescimento e frutificação na primavera.

Cada estádio de desenvolvimento e crescimento das plantas é fortemente limitado pelo ambiente, tanto pelos fatores edáficos como climáticos, e pelas técnicas culturais, as quais podem ter maiores efeitos na sobrevivência e produtividade das mesmas.

O pêssego maduro, como órgão de reserva, é constituído por 85 a 90\% de água, além dos sais minerais e outros sintetizados como carboidratos, lipídeos, protídeos, ácidos orgânicos, compostos fenólicos, flavonóides, carotenóides e substâncias voláteis.

O desenvolvimento do fruto do pessegueiro depende de sua capacidade para atrair carboidratos pela fotossíntese (Faust,1989). As relações hormonais são, em grande parte, diretamente responsáveis pelo sucesso de frutificação. A fixação do fruto à planta depende do balanço exato entre auxinas, giberilinas, citocininas, e etileno (WEESTWOOD, 1978). 
O desenvolvimento dos frutos e as reservas de carboidratos, aparece pois, como um fator decisivo e extremamente importante ao discernimento e adoção de técnicas culturais, como poda, raleio de frutos, tratamentos fitossanitários, nutrição e uso de reguladores vegetais.

Alguns outros autores afirmam que a fase III do crescimento de frutos de pêssego se caracteriza pela grande necessidade de carboidratos, que se acumulam, ocasionando uma competição entre o desenvolvimento vegetativo e reprodutivo durante essa fase. 


\section{Material e Métodos}

\subsection{Caracterização da Área Experimental}

O experimento foi conduzido no pomar experimental do Departamento de Produção Vegetal da Escola Superior de Agricultura "Luiz de Queiroz", situado no município de Piracicaba, Estado de São Paulo, cujas coordenadas geográficas são: latitude $22^{\circ} 42^{\prime} 30^{\prime}$ ', longitude $47^{\circ} 38^{\prime} 00^{\prime}$ ' e altitude de 564 metros.

O clima da região, conforme a classificação de Köppen, é do tipo Cwa: tropical de altitude, com três meses mais secos (junho/julho/agosto) e chuvas de verão. A temperatura média do mês mais quente é maior do que $22^{\circ} \mathrm{C}$ e do mês mais frio não é inferior a $16^{\circ} \mathrm{C}$, com média anual de $21,1^{\circ} \mathrm{C}$, precipitação média de $1253 \mathrm{~mm}$ ano ${ }^{-1}$, umidade relativa do ar de 74\% e insolação média de 101,5 horas.

O solo da área experimental é classificado como Terra Roxa Estruturada Eutrófica A moderado textura argilosa, correspondendo ao Kandudalfil Eutrudox.

\subsection{Cultivar}

A cultivar utilizado foi 'FLORDAPRINCE', pessegueiro originário da Flórida, Estados Unidos, que encontrou boa adaptação nas condições climáticas de inverno brando do Estado de São Paulo, Segundo Ojima et al., (1984) esta cultivar destaca-se pela alta produtividade, pelo aspecto atraente dos frutos, intenso colorido amareloavermelhado e, principalmente, pela alta precocidade de maturação. $O$ fruto é de tamanho médio, 80 a 90 gramas. O ciclo da florada a colheita é de 85 a 90 dias. 


\subsection{Sistema de Condução}

As mudas, enxertadas em pêssego 'Okinawa' foram transplantadas em agosto de 2001. O espaçamento adotado foi de 3,0 X 1,2 metros, correspondendo a 2777 plantas $\mathrm{ha}^{-1}$. As plantas foram conduzidas em sistema líder central, e todas receberam as práticas de irrigação, nutrição, quebra de dormência, tratamento fitossanitários, desbrotas, normalmente utilizadas.

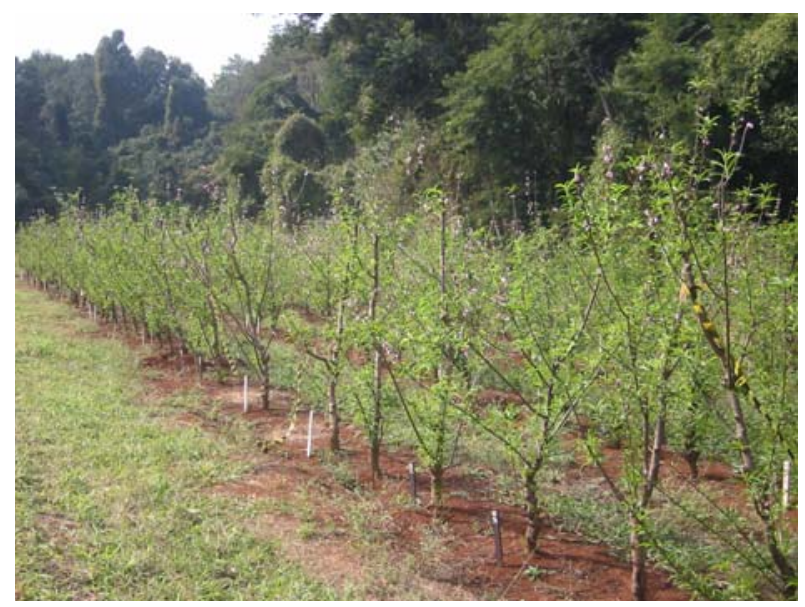

Figura 1 -Vista da área experimental e o sistema de condução adotado

\subsection{Definição dos Tratamentos}

Os tratamentos forma definidos através da associação de diferentes práticas, com o objetivo primordial de produzir frutos em quantidade e qualidade.

\subsubsection{Poda}

Com relação a prática da poda esta foi realizada da seguinte forma:

Todas as plantas passaram pela poda de produção, na fase de dormência no mês de junho.

Os tratamentos relacionados ao tipo de poda foram com poda de renovação e sem poda de renovação. 
Poda de renovação é realizada no primeiro mês após a colheita em que são podados todos os ramos, que produziram ou não, reiniciando o crescimento vegetativo e a diferenciação das gemas para a produção da safra seguinte (Borba, 2002).

As plantas que não passaram pela poda de renovação receberam tratamentos fitossanitários diferentes após a colheita com o intuito de manter ou não as folhas, sendo aquelas que receberam tratamentos denominadas de plantas sem desfolha de verão, e aquelas que não receberam tratamentos fitossanitários denominadas de plantas com desfolha de verão.

As plantas que não sofreram a poda de renovação receberam poda verde onde foram suprimidos apenas os ramos produziram e brotações em excesso ou mal posicionados nas plantas (Borba, 2002).

Ressalta-se que nas plantas submetidas a poda de renovação, não foi utiliada a desfolha de verão, pois esta prática retarda o desfolhamento.

\subsubsection{Quebra de Dormência}

A quebra de dormência se deu nos dois anos do experimento no inicio do mês de junho. Foi aplicado uma solução de Cianamida Hidrogenada, cujo nome comercial é Dormex. A concentração utilizada foi de $0,5 \%$. Sendo que as plantas tiveram toda a sua parte molhada de forma uniforme e homogênea pela calda.

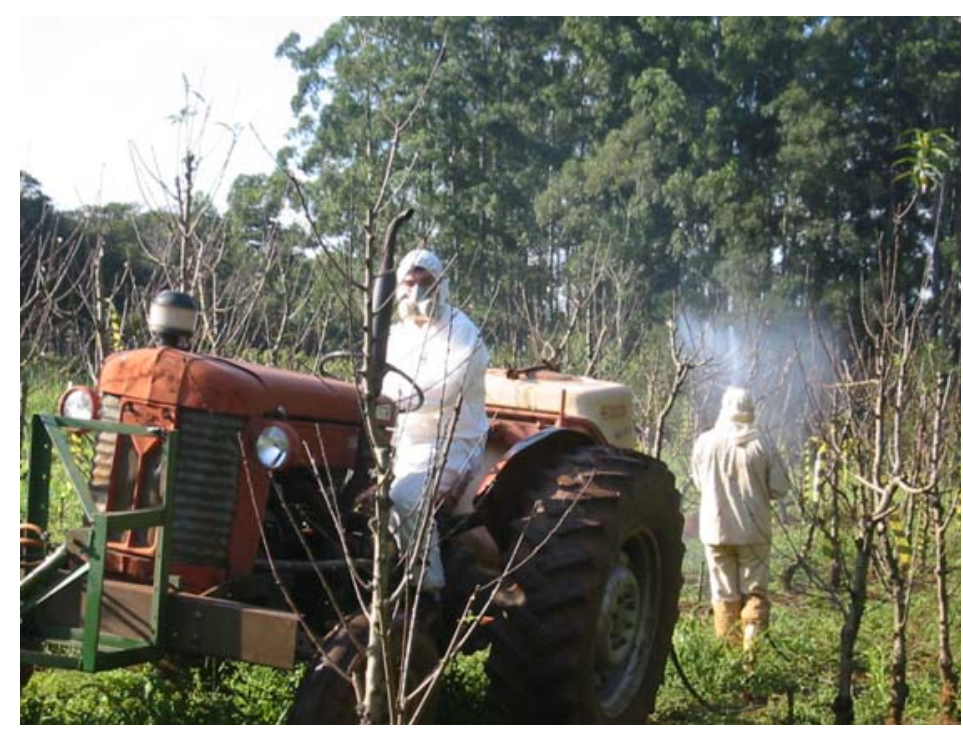

Figura 2 -Quebra de dormência das gemas das plantas através da aplicação do produto comercial Dormex no início do mês de junho 


\subsubsection{Regulador Vegetal}

Foi utilizado o Regulador Vegetal 2,4 DP (ácido 2,4-diclorofenoxipropiônico) nas concentrações de $0,12,5$ e $25 \mathrm{mg} \mathrm{L}^{-1}$, na fase de início do endurecimento do endocarpo - fase II da frutificação (Agusti, 1996).

A aplicação do regulador vegetal foi feito diretamente nos frutos, sendo aplicados apenas nos frutos através de pulverizador manual.
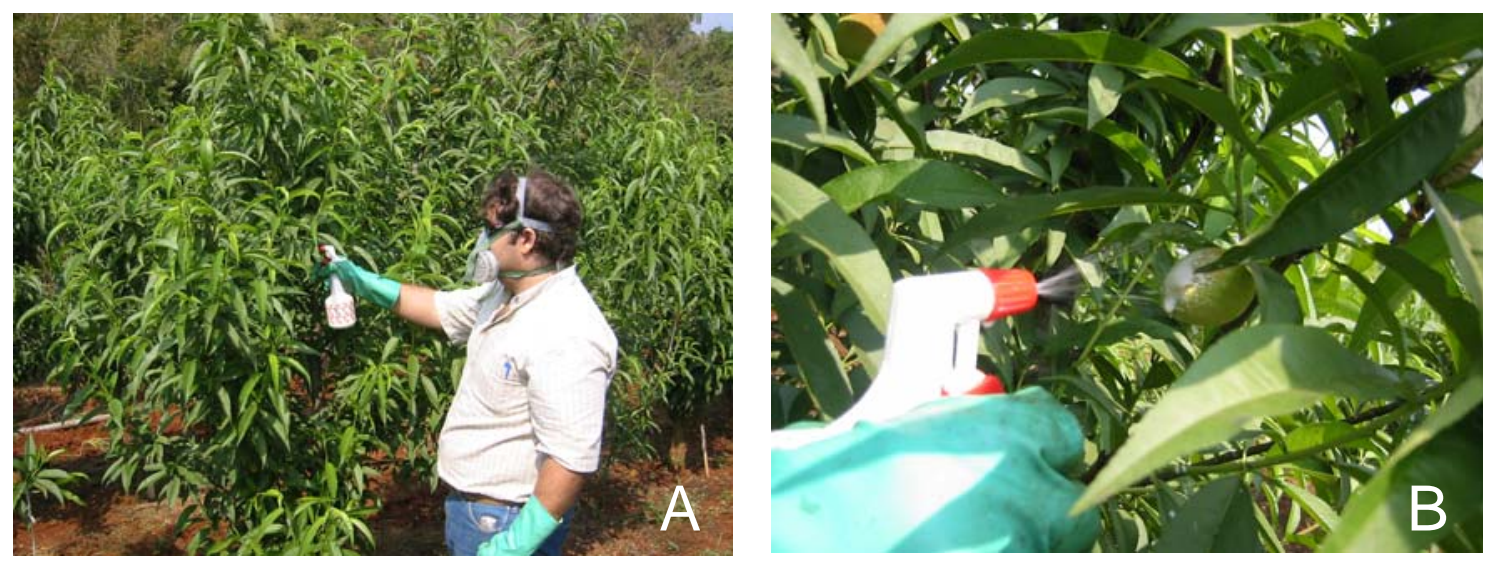

Figuras 3 - (A)Aplicação do regulador vegetal diretamente nos frutos, com o uso de pulverizador manual. (B) Vista aproximada da pulverização individual dos frutos Portanto os tratamentos foram:

T1- Sem desfolha de verão e $0 \mathrm{mg} \mathrm{L}^{-1}$ de 2,4 D.P.

T2- Sem desfolha de verão e $12,5 \mathrm{mg} \mathrm{L}^{-1}$ de 2,4 D.P.

T3- Sem desfolha de verão e $25 \mathrm{mg} \mathrm{L}^{-1}$ de 2,4 D.P.

T4- Poda de renovação e $0 \mathrm{mg} \mathrm{L}^{-1}$ de 2,4 D.P.

T5- Poda de renovação e $12,5 \mathrm{mg} \mathrm{L}^{-1}$ de 2,4 D.P.

T6- Poda de renovação e $25 \mathrm{mg} \mathrm{L}^{-1}$ de 2,4 D.P.

T7- Desfolha de verão e $0 \mathrm{mg} \mathrm{L}^{-1}$ de 2,4 D.P.

T8- Desfolha de verão e $12,5 \mathrm{mg} \mathrm{L}^{-1}$ de 2,4 D.P.

T9- Desfolha de verão e $25 \mathrm{mg} \mathrm{L}^{-1}$ de 2,4 D.P.

\section{Variáveis Analisadas}

4.1 Crescimento dos ramos - para cada tratamento e repetição foram medidos em $\mathrm{cm}$ o crescimento de 4 ramos, a cada 10 dias após a brotação, nos dois sistemas de poda. 
4.2 Crescimento dos frutos - para cada tratamento e repetição, e em dois frutos por ramo, estes mensurados com a utilização de um paquímetro digital, a cada 10 dias após o pegamento.

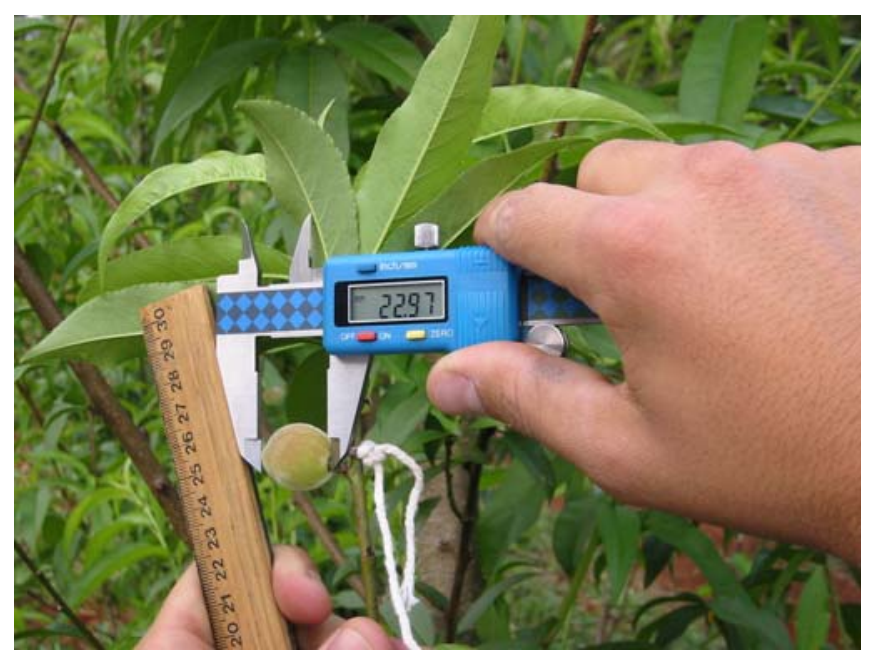

Figura 4 -Medição de frutos com o auxílio de paquímetro digital Digimess

4.3 Florescimento efetivo - data da plena floração - foi computado da data da plena floração ( $75 \%$ de flores totalmente abertas) de cada planta.

4.4 Densidade de Floração - foi utilizada a metodologia preconizada por Westwood (1978). Um total de 6 ramos por planta foi contado, anotando-se o número de gemas floríferas e vegetativas. A densidade floral determinada em percentagem do total de gemas, através da seguinte fórmula:

Percentagem de Flor $=$

Gemas de Flor X 100

Gemas Vegetativas + Gemas de Flor

\subsection{Qualidade das Frutas}

4.5.1 Peso e tamanho dos frutos - A determinação do peso médio das frutas foi determinada pela divisão do peso total colhido por planta pelo número de frutas. A medição do diâmetro médio foi efetuada em 10 frutas de cada planta, através de um paquímetro, avaliando-se o diâmetro longitudinal e o transversal. 
4.5.2 Coloração - Foi avaliada a cor da casca em dois locais de cada pêssego, utilizando-se equipamento MINOLTA CHROMA MATER, sendo os resultados expressos como valor L, a e b. A coloração será determinada em 5 frutas de cada planta.

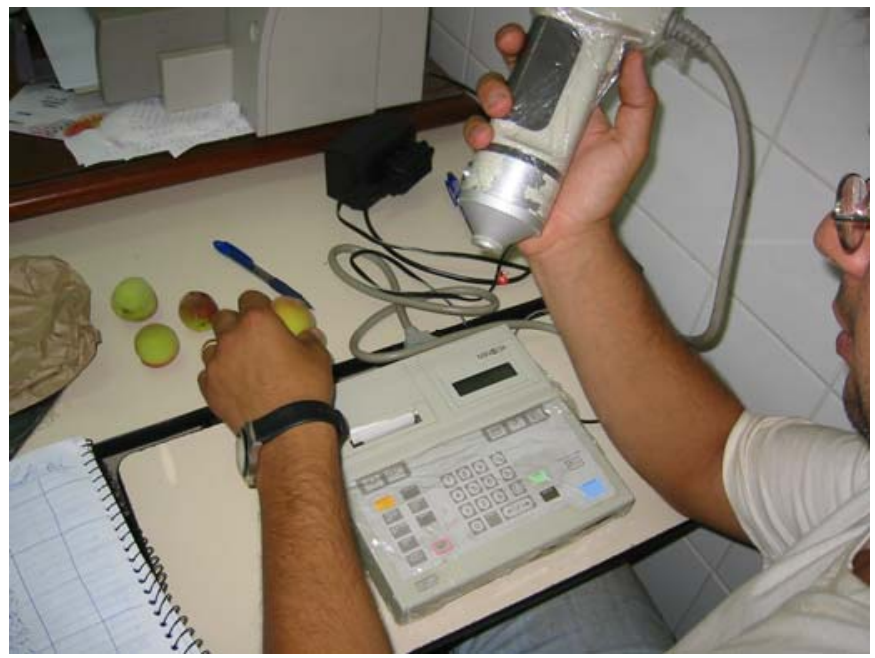

Figura 5 -Vista do aparelho utilizado para aferir a coloração dos frutos

4.5.3 Teor de Sólidos Solúveis Totais - Uma gota de suco puro de cada amostra foi colocado sobre o prisma de um refratômetro de mesa marca ABBÉ e a leitura foi feita em Brix, com correção da temperatura para $20^{\circ} \mathrm{C}$. O suco foi extraído de um total de 5 frutas para cada planta.

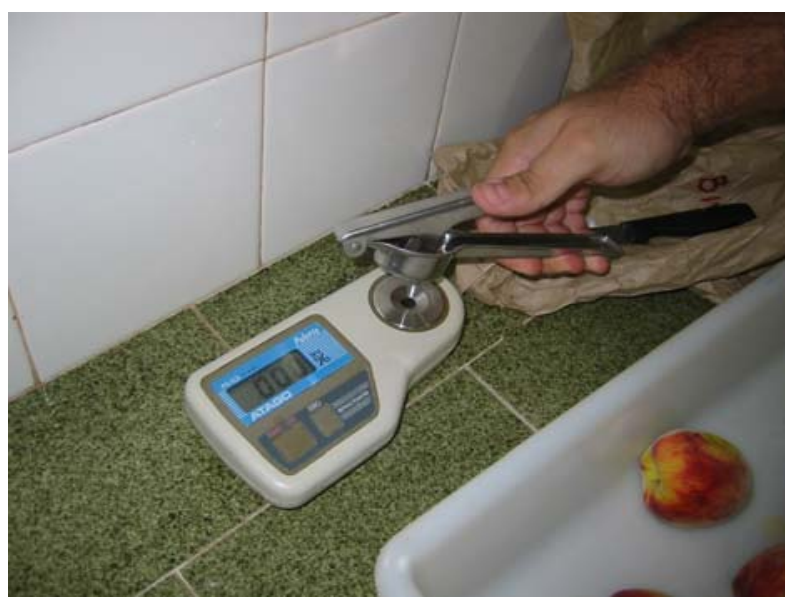

Figura 6 -Vista do refratômetro utilizado para aferição do teor de sólidos solúveis totais dos frutos 
4.6 Carboidratos - foram determinadas as concentrações de carboidratos não estruturados em raízes e ramos, a cada 45 dias, a partir da $1^{\text {a }}$ poda de renovação. As amostras foram levadas para serem secas em estufas, e assim que estavam secas eram moídas e levadas para se fazer a determinação dos níveis de carboidratos nos tecidos vegetais.
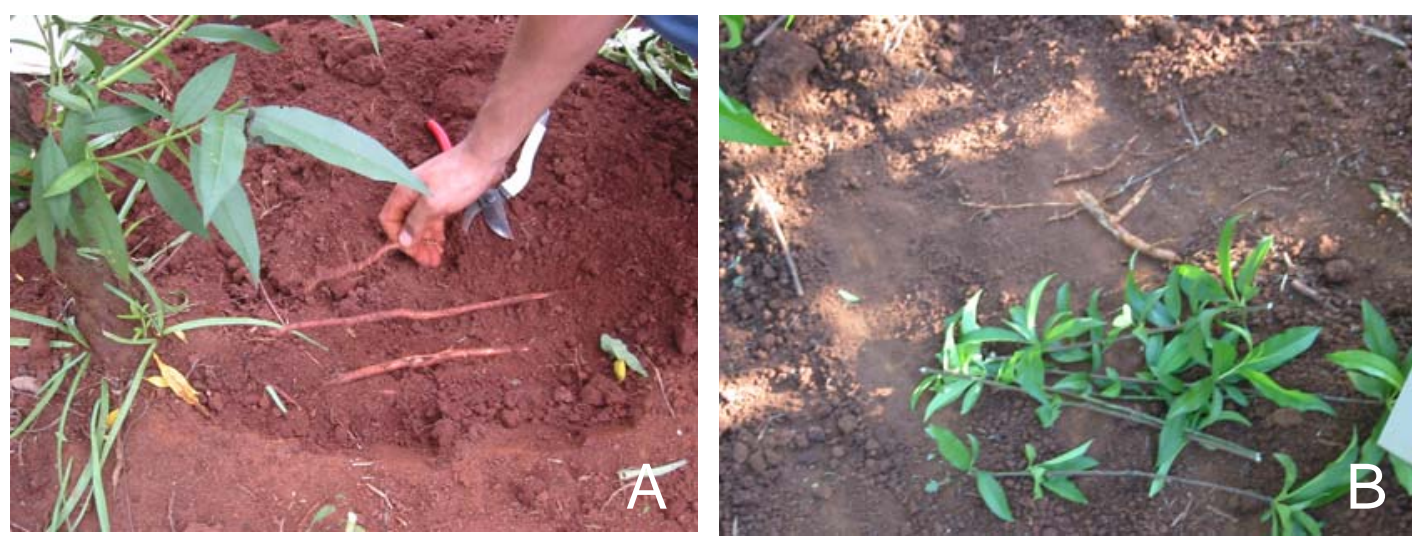

Figura 7 -Amostragem (A) raízes e (B) ramos
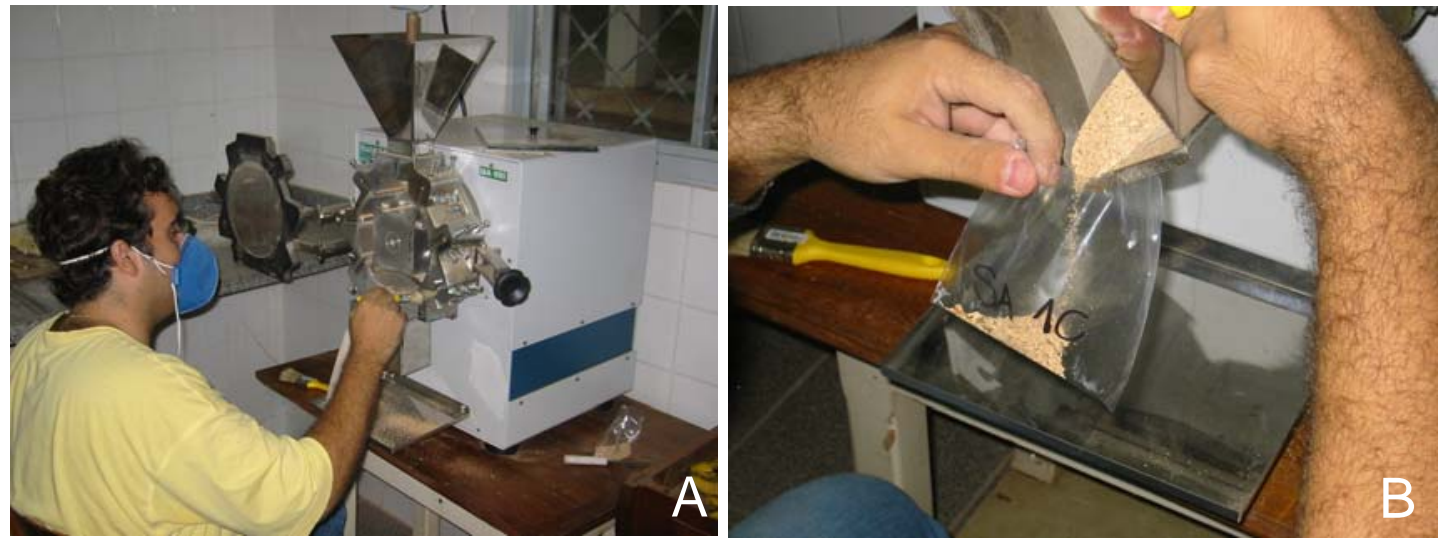

Figuras 8 - (A)Moagem de ramos e raízes, (B) recolhimento do material moído para análise dos níveis de carboidratos

A determinação da concentração de carboidratos não estruturados em raízes e ramos foi feita através da seguinte metodologia:

\subsubsection{Método para determinação de carboidratos não estruturados}

- pesar em papel alumínio 1g. de material seco e moído.

- transferir para erlenmeyer de $250 \mathrm{ml}$. 
- adicionar $100 \mathrm{ml}$ de água fervente e aquecer em banho-maria $\left(80^{\circ} \mathrm{C}\right)$ por 30 minutos.

- filtrar em funil com algodão para balão volumétrico de 500ml.

- completar o volume com água destilada.

\section{Preparo dos padrões:}

- solução de glicose : dissolver $0,1 \mathrm{~g}$ de glicose em $500 \mathrm{ml}$ de água destilada e transferir para balão volumétrico de $1000 \mathrm{ml}$ completando o volume.

- tomar 4 balões volumétricos de $100 \mathrm{ml}$, colocar $20 \mathrm{ml}$ da solução de glicose no primeiro, $40 \mathrm{ml}$ no segundo, $60 \mathrm{ml}$ no terceiro e $80 \mathrm{ml}$ no quarto.

- completar o volume de todos os balões com água destilada.

\section{Marcha para Determinação:}

\section{Amostras:}

- pipetar, em tubos de ensaio, $2 \mathrm{ml}$ do extrato, fazer duas repetições por amostra

- adicionar $1 \mathrm{ml}$ de solução de fenol a 5\%

- adicionar 5ml de ácido sulfúrico concentrado em 10 segundos, dirigindo o ácido para o meio da amostra

- deixar em repouso por 10 minutos

- esfriar em água corrente e agitar

- ler em fotocolorímetro, com filtro $510 \mathrm{~nm}$, em absorbância, zerando o aparelho com água destilada.

Padrões:

- repetir o procedimento anterior, lembrando que o padrão 0 deve ser feito com $2 \mathrm{ml}$ de água destilada.

\section{Preparo da solução de fenol 5\%}

- pesar 50g de fenol e diluir em Becker contendo aproximadamente 50ml de água destilada. Transferir para balão volumétrico de $100 \mathrm{ml}$ e completar o volume.

\section{Cálculos:}

- os cálculos são feitos colocando-se os dados em programa de computar (planilha eletrônica Excel) 


\subsection{Delineamento Experimental}

O delineamento foi de blocos ao acaso, constando de 9 tratamentos e 4 repetições. Cada parcela foi composta por 4 plantas. Os dados foram submetidos as análises de variância e à comparação das médias pelo Teste de Tukey.

As analises estatísticas foram feitas utilizando o programa SISVAR. 


\section{Resultados e Discussões}

\subsection{Crescimento dos ramos}

O pessegueiro possui uma vegetação moderada e um único surto de crescimento por ano, cujo início se verifica na primavera (Alvarenga \& Fortes, 1985).Para as condições do estado de São Paulo, em que a quebra de dormência é realizada no final de outubro este surto de crescimento ocorre durante o inverno.

Verificou-se uma variação muito grande do tamanho dos ramos, variando de 10 a $60 \mathrm{~cm}$, isto já era esperado, pois diversos autores relatam que os ramos podem ser classificados de acordo com a distribuição das gemas de flor, e classificam-se em mistos, brindilas, dardos ou ladrões. Os ramos mistos, de comprimento variável entre $20 \mathrm{~cm}$ e $100 \mathrm{~cm}$, são portadores de gemas de flor e lenho, terminando geralmente em gema de lenho. Em muitas cultivares e nas plantas jovens, eles contribuem de forma sensível para a produção. Em árvores novas e muito vigorosas, são propensos á ramificação, formando galhos antecipados, semelhantes às brindilas. As brindilas de comprimento de $15 \mathrm{~cm}$ a $30 \mathrm{~cm}$ portam em sua maioria gemas de flor, terminando tanto com gema de lenho com de flor. Os ramos chamados dardos são curtos, e possuem gema apical de lenho e numerosas gema de flor. Os chamados ramos ladrões são ramos muito vigorosos, que crescem em posição vertical e emitem numerosos ramos antecipados, mas possuem principalmente gemas de lenho (Embarpa, 1984). 


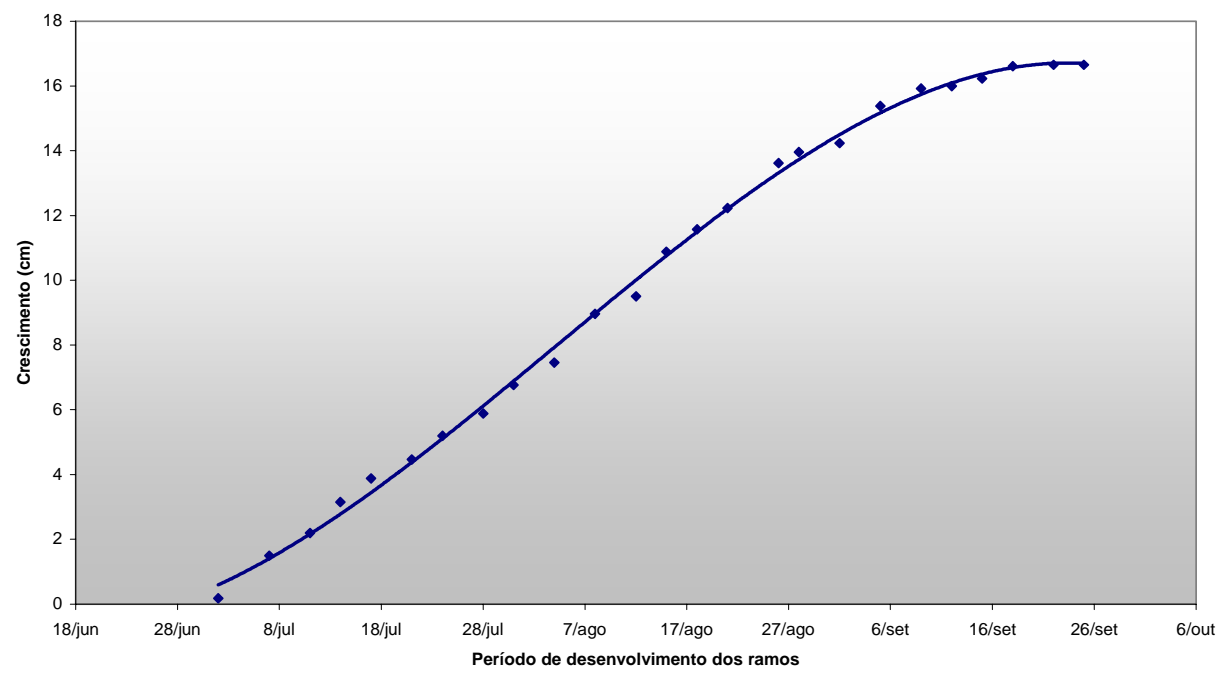

Figura 9 - Gráfico demonstrando o crescimento médio dos ramos de pessegueiro cultivar 'Flordaprince', em Piracicaba

Ao observar o gráfico é possível verificar o crescimento do ramo se deu de forma praticamente linear nos primeiros 65 dias. Borba (2002), estudando o crescimento de ramos na cultiva Ouromel 2, no período de verão, registrou a parada de crescimento dos frutos por volta dos 45 dias. No final do mês de agosto, em torno de 60 dias, a maioria dos ramos monitorados haviam cessado seu crescimento. Esse período mais prolongado do que aquele encontrado por Borba (2002) pode ser justificado pelo fato de serem cultivares distintas, épocas de avaliação distintas, ou ainda que devido ao fato das plantas utilizadas nesse experimento serem mias jovens, cerca de 3 anos, se comparadas às utilizadas por Borba (2002), com cerca de 5 anos. 


\subsection{Crescimento dos frutos}

O crescimento médio dos frutos apresentou o comportamento na forma de uma curva sigmóide dupla. Esse comportamento esta de acordo com diversos autores (Powell \& Pratti, 1966; Crane, 1969; Lilien-Kipnis \& Lavee, 1971).

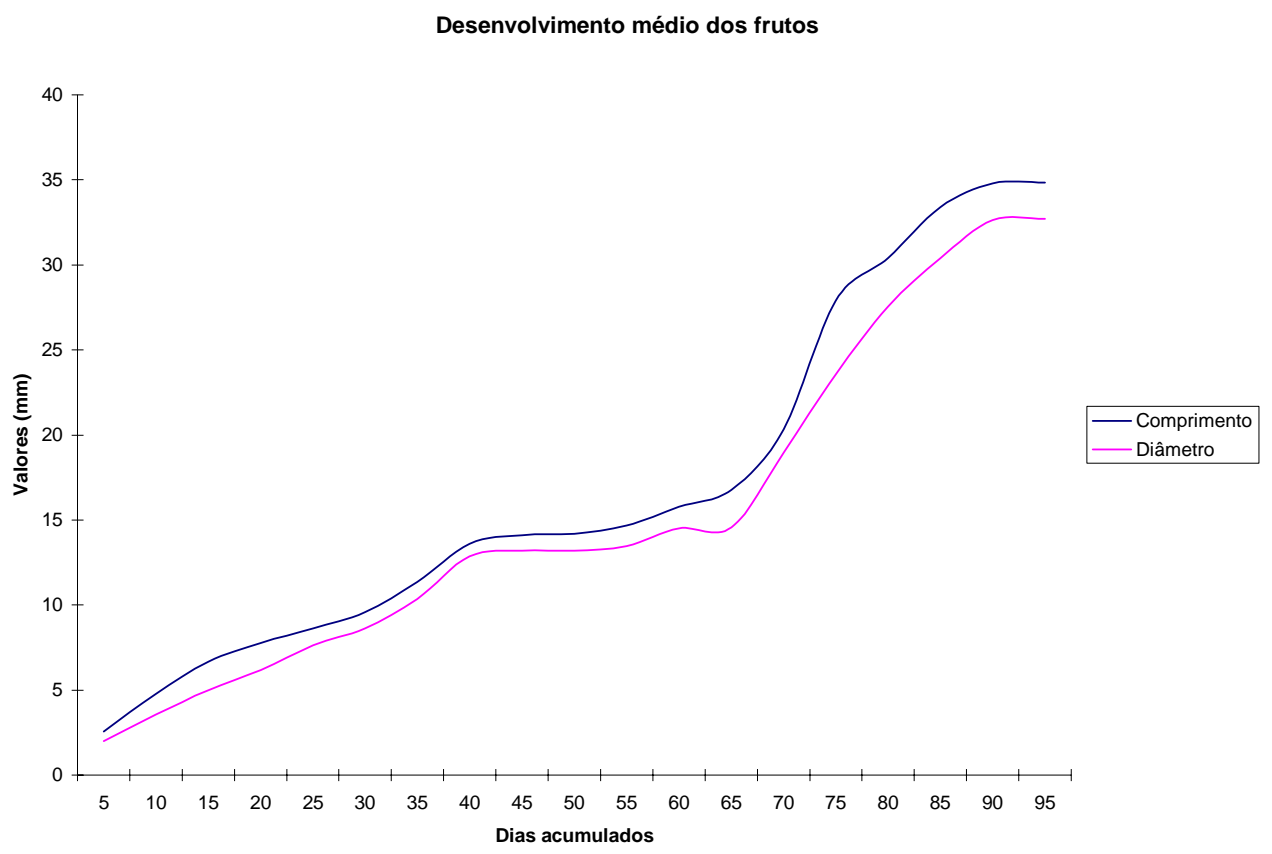

Figura 10 - Gráfico ilustrando o comportamento de crescimento médio dos frutos de pessegueiro cultivar 'Flordaprince', em Piracicaba

O crescimento dos frutos e dos ramos se deu de forma concomitante, isso discorda de Borba (2002), esse comportamento provavelmente se deve ao fato de que as plantas estudadas nesse experimento são jovens, com aproximadamente 3 anos de idade, estando, portanto ainda em formação, com isso existe uma competição entre os frutos e os ramos pelas reservas da planta. Essa competição pode ter sido a causa da produção de frutos de tamanho reduzidos.

\subsection{Florescimento}

O florescimento efetivo foi computado através data da plena floração (75\% de flores totalmente abertas) de cada planta.O florescimento efetivo ocorreu de 4 a 10 de julho 
Para se caracterizar a densidade de floração foi utilizada a metodologia preconizada por WESTWOOD (1978). Um total de 6 ramos por planta foi contado, anotando-se o número de gemas floríferas e vegetativas. A densidade de floração nos diversos tratamentos está expressa na tabela 1

Tabela 1. Densidade de Floração da cultivar Flordaprince submetidos aos diferentes tratamento em Piracicaba, SP, 2004

\begin{tabular}{|c|c|}
\hline Tratamentos & Densidade de Floração (\%) \\
\hline T1 - Sem desfolha de verão e $0 \mathrm{mg} . \mathrm{L}^{-1}$ de $2,4-\mathrm{DP}$ & 60,884 \\
\hline T2 - Sem desfolha de verão e $12,5 \mathrm{mg} . \mathrm{L}^{-1}$ de 2,4-DP & 56,856 \\
\hline T3 - Sem desfolha de verão e $25 \mathrm{mg} . \mathrm{L}^{-1}$ de 2,4 -DP & 60,204 \\
\hline T4 - Poda de renovação e 0 mg.L $\mathrm{L}^{-1}$ de $2,4-\mathrm{DP}$ & 55,631 \\
\hline T5 - Poda de renovação e 12,5 mg. $\mathrm{L}^{-1}$ de $2,4-\mathrm{DP}$ & 58,077 \\
\hline T6 - Poda de renovação e $25 \mathrm{mg} . \mathrm{L}^{-1}$ de 2,4 -DP & 58,255 \\
\hline T7 - Com desfolha de verão e 0 mg.L ${ }^{-1}$ de 2,4-DP & 60,061 \\
\hline T8 - Com desfolha de verão e 12,5 mg.L $\mathrm{L}^{-1}$ de 2,4-DP & 57,265 \\
\hline T9 - Com desfolha de verão e $25 \mathrm{mg} . \mathrm{L}^{-1}$ de 2,4 -DP & 58,228 \\
\hline
\end{tabular}

Ao observar a tabela 1, podemos aferir que o pessegueiro possui uma alta densidade de floração o que concorda com Simão (1998), o qual ainda relata que as gemas floríferas apresentadas por árvore variam com a idade, a variedade, o vigor, a poda e de ano para ano. Pode-se verificar que os tratamentos não influenciaram na densidade de floração. Portanto a diferença de produção que ocorreu entre os tratamentos não foi devido à densidade de floração, ou seja, mesmo as plantas com poda de renovação tiveram condições de se desenvolver e promover a diferenciação das gemas de flor.

Esta observação difere da observada nos trabalhos de Barbosa (1989) onde o autor verificou que as podas drásticas provocaram um efeito supressivo no desenvolvimento de gema vegetativas e floríferas, causando sensível redução na densidade de floração dos ramos. 


\subsection{Produção e qualidade dos frutos}

\subsubsection{Produção}

Na Tabela 2 tem-se os resultados na análise dos valores obtidos com relação a produção e número de frutos nos tratamentos com diferentes sendo a produção expressa em $\mathrm{kg}$ de frutos por planta.

Tabela 2. Produção em kg de frutos por planta e número de frutos por plantas de pêssego cultiva 'Flordaprince', em Piracicaba, em função dos diferentes tipos de podas

\begin{tabular}{ccc}
\hline Tratamento & Produção Total $\left(\mathrm{kg} \cdot\right.$ planta $\left.^{-1}\right)$ & $\mathrm{N}^{\circ}$ de frutos \\
\hline Sem desfolha de verão & $4,270 \mathrm{a}$ & $100 \mathrm{a}$ \\
Com poda de Renovação & $1,340 \mathrm{~b}$ & $28 \mathrm{~b}$ \\
Com desfolha de verão & $3,389 \mathrm{ab}$ & $66 \mathrm{ab}$ \\
CV (\%) & 46,28 & 41,97 \\
\hline
\end{tabular}

- médias seguidas pela mesma letra em minúsculo na coluna e maiúsculo na linha, não diferem entre si pelo Teste de Tukey, ao nível de 5\% de probabilidade.

Observa-se na Tabela 2 que houve diferença significativa com relação à produção total de frutos por planta e o número de frutos por tratamento. $\mathrm{O}$ tratamento no qual não ocorreu desfolha de verão apresentou uma produção total maior de frutos por planta, bem como apresentou um maior número de frutos por planta. Esses resultados são concordantes com os encontrados por Nienow (1997), o qual verificou que a poda de renovação realizada no final da primavera, embora tenha retardado o desfolhamento e evitado o florescimento no final do verão, afetou a produtividade do pomar. Contudo Marini (1985) ao estudar podas dormentes e podas de verão, não constatou nenhuma diferença na produção.

O tratamento sem desfolha de verão apresentou os melhores resultados sendo significativamente superior ao tratamento com poda de renovação. O tratamento com desfolha de verão apresentou um desempenho intermediário não diferindo estatisticamente dos outros tratamentos. Isso demonstra que a presença de folhas no 
período após a colheita é de fundamental importância para que a planta continue fazendo fotossíntese e acumulando reservas que serão utilizadas nos ciclos seguintes.

A utilização do regulador vegetal 2,4-DP não promoveu qualquer influência na produção, nem no número de frutos produzidos por planta.Esses resultados discordam dos encontrados por Blanco (1990) e Benito et al. (1995), os quais observaram aumento na produção.

\subsubsection{Qualidade dos frutos}

Segundo diversos autores qualidade é o conjunto de características de um produto que influenciam a decisão de compra pelo consumidor. Os principais atributos da qualidade são a aparência, a textura, o sabor, o valor nutritivo e a segurança. Segundo Wills et al.(1998), qualidade é um conceito muito difícil de definir, estando relacionada ao interesse de cada elo da cadeia produtiva. Os critérios de qualidade são a aparência, o sabor, a textura e o valor nutritivo. Entre esses critérios foi avaliada a coloração, parte constituinte da aparência, o teor de sólidos solúveis, parte do sabor.

Na Tabela 3 tem-se os resultados da análise dos valores obtidos, com relação a qualidade dos frutos colhidos nos tratamentos com diferentes tipos de poda, massa média dos frutos expressa em g. fruto $^{-1}$, comprimento e diâmetro dos frutos em mm, teor de sólidos solúveis expresso em \%, a coloração expressa através do valor do ângulo de cor $(\mathrm{H})$, tanto da cor de fundo quanto da cor da face exposta ao sol. 
Tabela 3.Resultados da analise da qualidade dos frutos da cultivar Flordaprince, em Piracicaba, sendo a massa média dos frutos expressa em g.fruto ${ }^{-1}$, comprimento e diâmetro dos frutos em mm, teor de sólidos solúveis expresso em \%, a coloração expressa através do valor de $\mathrm{H}$, em função das diferentes podas

\begin{tabular}{|c|c|c|c|c|c|c|}
\hline \multirow[b]{2}{*}{ Tratamento } & \multirow{2}{*}{$\begin{array}{c}\text { Massa } \\
\text { Média } \\
\text { (g.fruto }^{-1} \text { ) }\end{array}$} & \multirow[b]{2}{*}{$\begin{array}{l}\text { Comprimento } \\
\text { (mm) }\end{array}$} & \multirow[b]{2}{*}{$\begin{array}{l}\text { Diâmetro } \\
\text { (mm) }\end{array}$} & \multirow{2}{*}{$\begin{array}{c}\text { Teor de } \\
\text { Sólidos } \\
\text { Solúveis } \\
\text { (\%) }\end{array}$} & \multicolumn{2}{|c|}{ Ângulo de Cor } \\
\hline & & & & & $\begin{array}{c}\text { Face } \\
\text { exposta }\end{array}$ & $\begin{array}{l}\text { Cor de } \\
\text { fundo }\end{array}$ \\
\hline $\begin{array}{c}\text { Sem } \\
\text { desfolha de } \\
\text { verão }\end{array}$ & $42,7 \mathrm{a}$ & 33,594 a & $32,174 \mathrm{a}$ & $6,30 \mathrm{a}$ & $65,315 \mathrm{a}$ & $118,353 \mathrm{a}$ \\
\hline $\begin{array}{l}\text { Com poda } \\
\text { de } \\
\text { renovação }\end{array}$ & $47,85 \mathrm{a}$ & 24,839 a & 23,219 a & $4,68 \mathrm{a}$ & $47,370 \mathrm{a}$ & $119,612 \mathrm{a}$ \\
\hline $\begin{array}{c}\text { Com } \\
\text { desfolha de } \\
\text { verão }\end{array}$ & $51,34 \mathrm{a}$ & 33,119 a & $32,273 \mathrm{a}$ & $6,67 \mathrm{a}$ & $62,236 \mathrm{a}$ & $116,261 \mathrm{a}$ \\
\hline $\mathrm{CV}(\%)$ & 23,78 & 20,26 & 20,01 & 19,65 & 19,88 & 17,77 \\
\hline
\end{tabular}

- médias seguidas pela mesma letra em minúsculo na coluna e maiúsculo na linha, não diferem entre si pelo Teste de Tukey, ao nível de 5\% de probabilidade.

Verifica-se na tabela 3 que não houve diferença significativa com relação à massa média, comprimento e diâmetro dos frutos, esses resultados concordam com Marini (1985), o qual estudou podas dormentes e podas de verão não encontrando nenhuma diferença com relação ao tamanho dos frutos. O teor de sólidos solúveis e coloração dos frutos não apresentaram diferenças significativas nos diferentes tipos de poda. Entretanto podemos ressaltar que nos tratamento com diferentes tipos de podas ocorreu um incremento significativo no número de frutos por planta, logo as plantas que não sofreram desfolha de verão obtiveram maior índice de pegamento de frutos. 
A Tabela 4 apresenta a análise dos valores obtidos com relação, massa média dos frutos expressa em g.fruto ${ }^{-1}$, comprimento e diâmetro dos frutos em mm, teor de sólidos solúveis expresso em \%, a coloração expressa através do valor do ângulo de cor $(\mathrm{H})$, tanto da cor de fundo quanto da cor da face exposta ao sol.

Tabela 4. Resultados da analise da qualidade dos frutos da cultivar Flordaprince, em Piracicaba, sendo a massa média dos frutos expressa em g.fruto ${ }^{-1}$, comprimento e diâmetro dos frutos em mm, teor de sólidos solúveis expresso em \%, a coloração expressa através do valor de $\mathrm{H}$, em função das diferentes concentrações do produto 2,4-DP

\begin{tabular}{|c|c|c|c|c|c|c|}
\hline \multirow[b]{2}{*}{ Tratamentos } & \multirow{2}{*}{$\begin{array}{c}\text { Massa } \\
\text { Média } \\
\left(\text { g.fruto }{ }^{-1} \text { ) }\right.\end{array}$} & \multirow[b]{2}{*}{$\begin{array}{l}\text { Comprimento } \\
\text { (mm) }\end{array}$} & \multirow[b]{2}{*}{$\begin{array}{l}\text { Diâmetro } \\
\text { (mm) }\end{array}$} & \multirow{2}{*}{$\begin{array}{c}\text { Teor de } \\
\text { Sólidos } \\
\text { Solúveis } \\
\quad(\%)\end{array}$} & \multicolumn{2}{|c|}{ Ângulo de Cor } \\
\hline & & & & & $\begin{array}{c}\text { Face } \\
\text { exposta }\end{array}$ & $\begin{array}{l}\text { Cor de } \\
\text { Fundo }\end{array}$ \\
\hline 0mg. $\mathrm{L}^{-1}$ & $45,34 \mathrm{a}$ & $29,609 \mathrm{a}$ & $27,205 \mathrm{a}$ & $7,39 \mathrm{a}$ & $77,673 \mathrm{a}$ & $126,078 \mathrm{a}$ \\
\hline $12,5 \mathrm{mg} \cdot \mathrm{L}^{-1}$ & $46,89 \mathrm{a}$ & $23,614 \mathrm{a}$ & $24,886 \mathrm{a}$ & $5,03 \mathrm{~b}$ & $45,157 \mathrm{~b}$ & $108,419 b$ \\
\hline $25 \mathrm{mg} \cdot \mathrm{L}^{-1}$ & $45,68 \mathrm{a}$ & $26,802 \mathrm{a}$ & $23,875 \mathrm{a}$ & $5,10 \mathrm{ab}$ & $51,169 \mathrm{~b}$ & $109,130 \mathrm{~b}$ \\
\hline CV (\%) & 23,78 & 20,26 & 20,01 & 19,65 & 19,88 & 17,77 \\
\hline
\end{tabular}

- médias seguidas pela mesma letra em minúsculo na coluna e maiúsculo na linha, não diferem entre si pelo Teste de Tukey, ao nível de 5\% de probabilidade.

Houve diferença significativa com relação ao teor de sólidos solúveis, tendo-se observado que o tratamento onde não houve aplicação do produto comercial apresentou um teor mais elevado de sólidos solúveis. Esses resultados são conflitantes daqueles encontrados por Agustí (1994a), o qual ao estudar a aplicação de $25 \mathrm{mg} . \mathrm{L}^{-1}$ na fase de endurecimento de caroço,constatou aumentou no teor de sólidos solúveis em frutos de damasco.

Não foi encontrada diferença significativa com relação ao tamanho dos fruto, esses resultados discordam daqueles encontrados por Blanco (1990) e Benito et al. (1995), os quais observaram um aumento no tamanho final dos frutos. 
Com relação a coloração dos frutos, foi possível observar que a aplicação do produto comercial 2,4-DP possibilitou uma melhor coloração dos frutos, tanto com relação à cor de fundo, como a cor da face exposta do fruto. Esse resultado também foi observado por Agustí (1994a, 1994b), Benito (1995), Vieira (2003).

As diferentes concentrações do produto comercial utilizado não apresentou diferença significativa no tocante à coloração dos fruto.

Um aspecto importante e, que merece ser destacado, foi a antecipação na colheita em cerca de 7 dias nos tratamentos em que se aplicou o produto comercial 2,4-DP, resultados esses concordantes com os obtido por Agustí (1994a, 1994b), Blanco (1990), Benito (1995). Por outro lado, Vieira (2003) ao estudar a aplicação de 2,4-DP e o anelamento de ramos, na cultivar de meia estação Biuti, não constatou antecipação da colheita.

\subsection{Carboidratos}

As determinações das concentrações de carboidratos não estruturados em raízes e ramos nas plantas submetidas à poda de renovação e nas plantas que não sofreram poda de renovação estão representadas nas respectivas Figuras 11 e Figura 12.

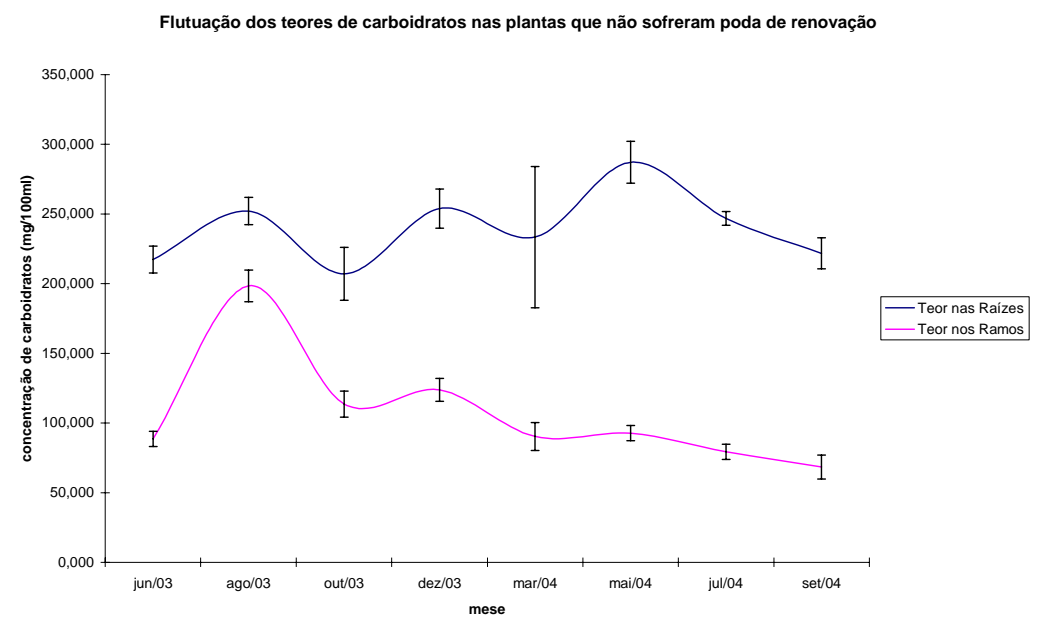

Figura 11-Flutuação dos teores de carboidratos nas raízes e nos ramos das plantas de pessegueiro cultivar 'Flordaprince', em Piracicaba que não sofreram poda de renovação 


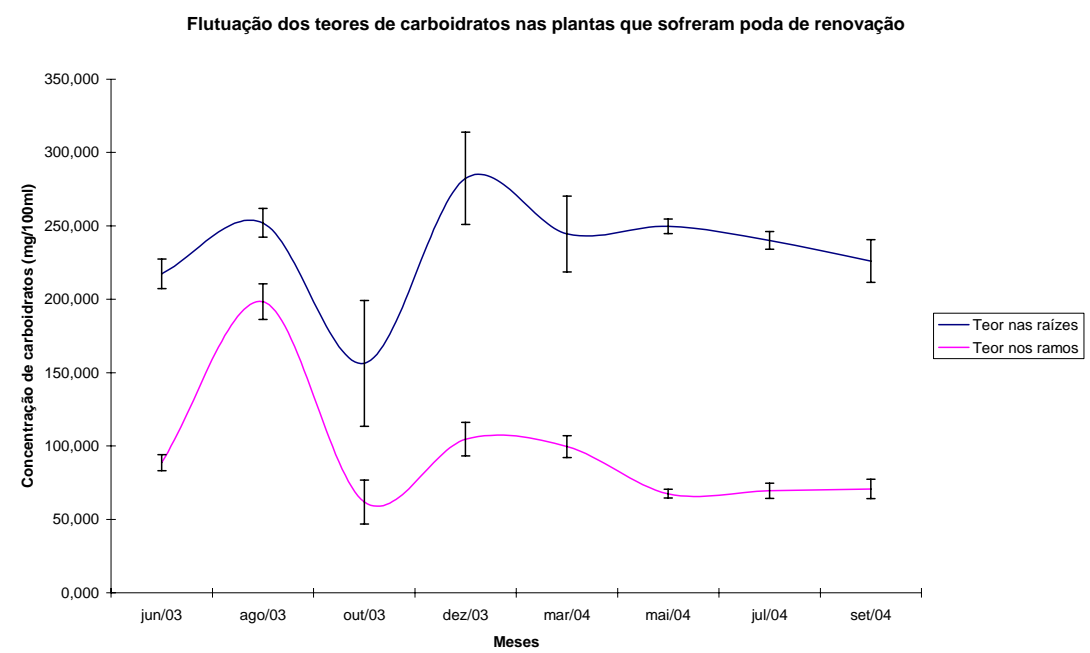

Figura 12-Flutuação dos teores de carboidratos nas raízes e nos ramos das plantas de pessegueiro cultivar 'Flordaprince', em Piracicaba que sofreram poda de renovação

Nas Figura 11 e 12 observa-se que a concentração de carboidratos varia de acordo com a época em que foram coletadas durante o ciclo da planta. Esse resultado está de acordo com Borba (2002). Constatou-se que existe um pico na concentração de carboidratos, tanto nas raízes como nos ramos, no mês de agosto, mês esse em que a planta estava em plena frutificação, portanto as reservas das plantas estavam sendo disponibilizadas para atender ao forte dreno causado pelo crescimento de frutos e de ramos. Entretanto era esperado que o pico de concentração de carboidratos ocorrido nos ramos, coincidisse com uma queda dos teores nas raízes, fato esse que não ocorreu. Provavelmente esse aumento inesperado na concentração de açúcares nas raízes podem ser em virtude das plantas possuírem uma reserva de amido suficientemente grande para suprir a demanda de carboidratos dos ramos sem que ocorresse queda nos teores de açúcares nas raízes. Após esse período de frutificação ocorreu uma diminuição nos teores de carboidratos nos ramos e acréscimo nas raízes. As concentrações de carboidratos nas raízes foram sempre superiores àquelas encontradas nos ramos, esse resultado concordam com os encontrados por Borba (2002), estudando as concentrações de carboidratos em ramos 
e raízes da cultivar Ouromel 2. As oscilações não significativas dos teores de carboidratos nas raízes no período de dezembro a maio podem estar relacionadas a surtos de crescimentos do sistema radicular. Segundo Faust (1989), a periodicidade do crescimento do sistema radicular depende, em grande parte, do crescimento da parte aérea e da carga de frutos da planta. Menciona ainda que o final do pico de crescimento inicial usualmente corresponde com o início do crescimento da parte aérea, e o segundo surto de crescimento do sistema radicular inicia-se assim que o crescimento da parte aérea cessa.

As Figuras 13 e 14 ilustram a flutuação das concentrações de carboidratos nas raízes e nos ramos das plantas que sofreram poda de renovação e na que não sofreram poda de renovação.

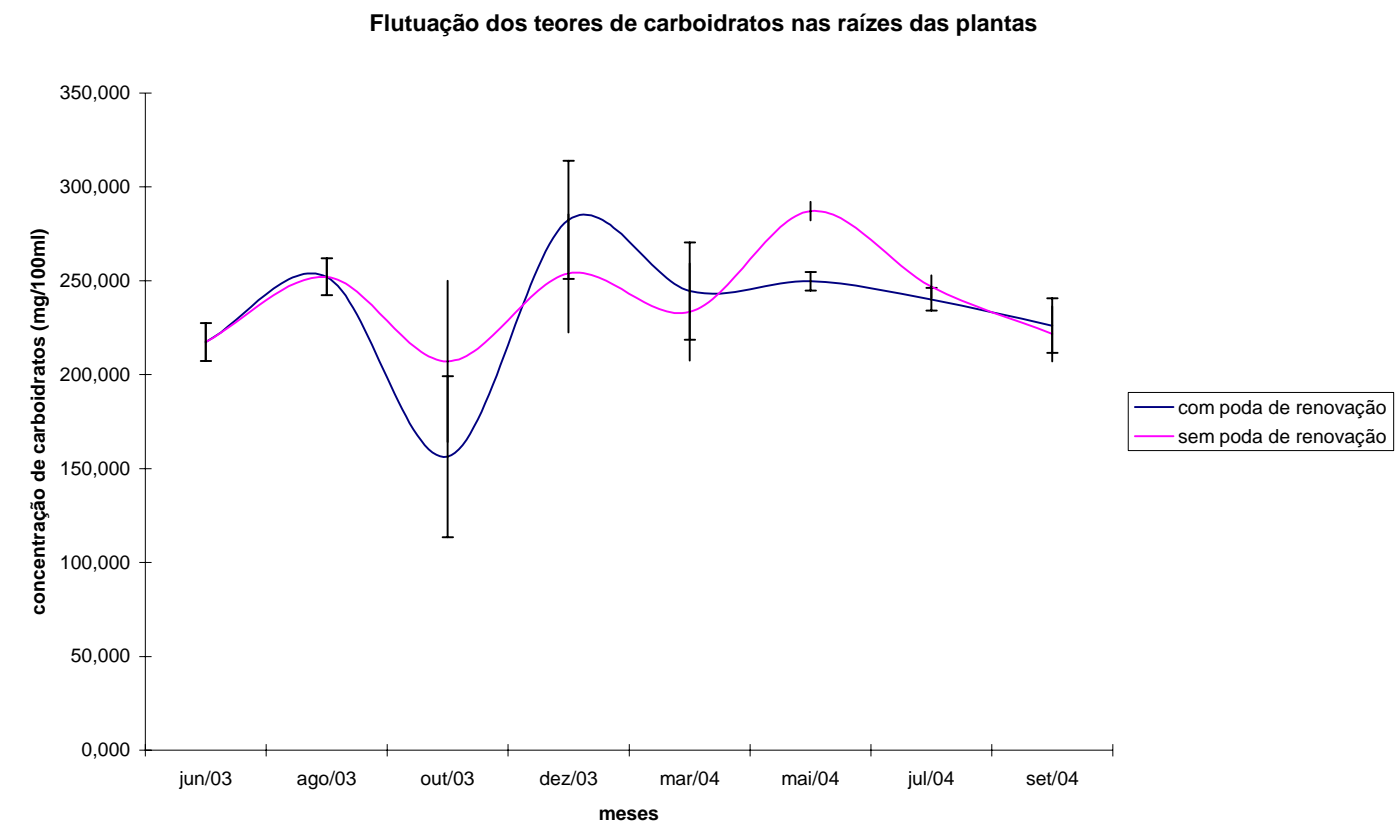

Figura 13- Flutuação dos teores de carboidratos nas raízes das plantas de pessegueiro cultivar 'Flordaprince', em Piracicaba, que sofreram e nas plantas que não sofreram poda de renovação 
Flutuação dos teores de carboidratos nos ramos das plantas

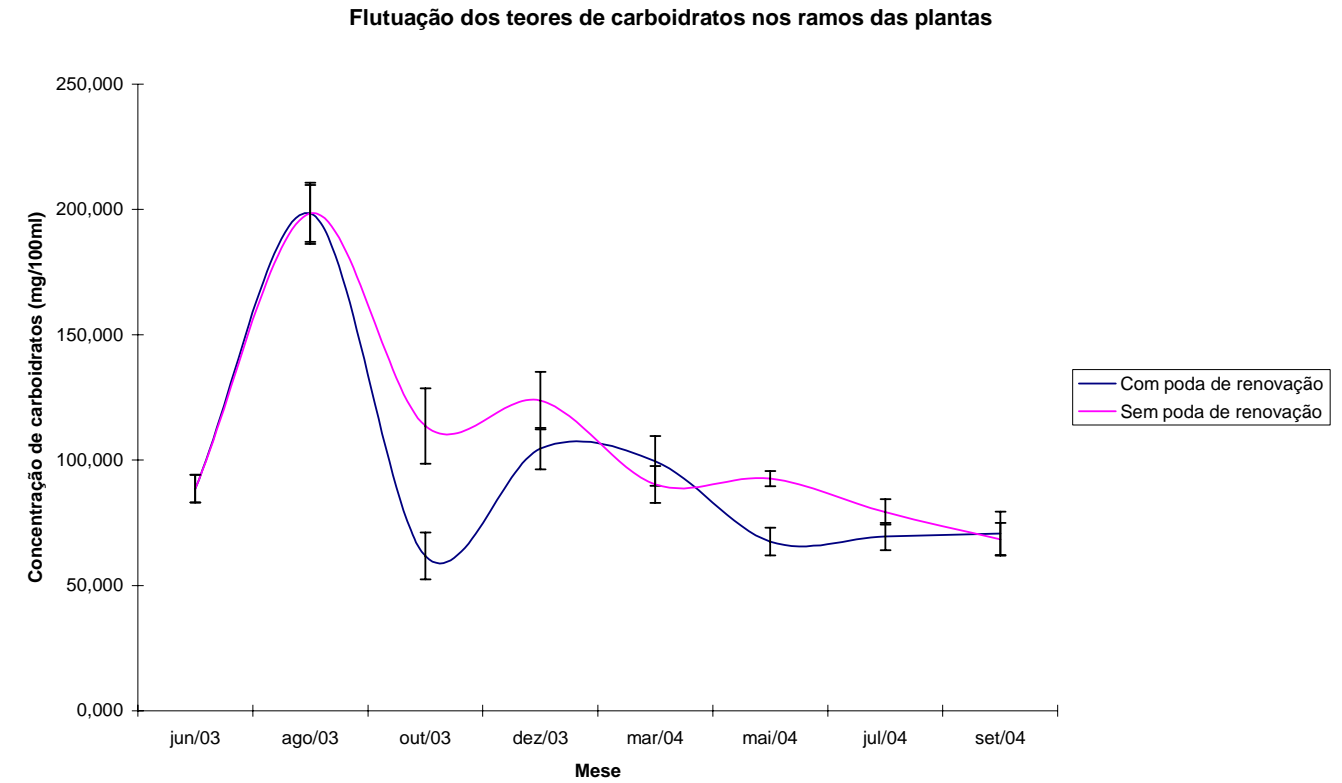

Figura 14- Flutuação dos teores de carboidratos nos ramos das plantas que sofreram e nas plantas de pessegueiro cultivar 'Flordaprince', em Piracicaba, que não sofreram poda de renovação

$\mathrm{Na}$ Figura 13 observa-se em todos os tratamentos, com e sem poda de renovação a ocorrência de uma queda na concentração de carboidratos nas raízes no mês de agosto, esse comportamento era esperado, uma vez que nesse mês existe uma grande demanda causada pelo crescimento dos ramos e frutos. Após a colheita, no mês de outubro ocorreu um aumento na concentração de carboidratos, uma vez que os frutos, principais drenos, foram retirados da planta, possibilitando assim um aumento na concentração de carboidratos que podem ser utilizados no metabolismo da planta ou acumulados nas raízes na forma de amido.Esse comportamento concorda com Borba et al. (no prelo) que consideram que existem dois períodos distintos no fluxo de carboidratos nas raízes de pessegueiros cultivados no estado de São Paulo, sendo o primeiro fluxo o de acúmulo de carboidratos nas raízes, que acontece do período após a colheita até a dormência, período esse de outubro a maio, e o segundo fluxo de carboidratos onde ocorre a mobilização das reservas das raízes para a copa, causando a queda nos teores de carboidratos nas raízes nas determinações realizadas em julho e setembro. 
Na Figura 14 nota-se que houve uma queda na concentração de carboidratos nos ramos no mês de agosto, essa queda esta relacionada a presença de frutos e ramos em crescimento, os quais são fortes drenos.

Observando-se as Figuras 13 e 14 nota-se que nos meses de dezembro a maio ocorreu uma queda nos teores da concentração de carboidratos nos ramos, atendendo o dreno, que após a colheita passa a ser as raízes, órgãos as quais se desenvolvem e acumulam os fotoassimilados na forma de amido. 


\section{Conclusões}

Com os resultados obtidos podemos concluir que:ocorre flutuação dos concentração de carboidratos solúveis tanto nas raízes como nos ramos de acordo com a época em que foram coletados, e ainda que os teores de carboidratos solúveis nas raízes são sempre superiores àqueles encontrados nos ramos;

A poda de renovação realizada no primeiro mês após a colheita em que são podados todos os ramos, que produziram ou não, reiniciando o crescimento vegetativo e a diferenciação das gemas para a produção da safra seguinte, provoca a queda na produção.

A aplicação do regulador vegetal 2,4-DP antecipa a colheita em cerca de 7 dias e intensifica a coloração dos frutos. 


\section{Referências Bibliográficas}

AGUSTÍ, M.; JUAN, M.; ALMELA, V.; SPERONI, C. The effect of 2,4-DP on fruti development in apricots (Prunus armenica L.). Scientia Horticulturae, n.57, p.5157, 1994a.

AGUSTI, M.; JUAN, M.; SPERONI, C.; ALMELA, V. Estimulo del desarrollo de los frutos de hueso mediante la aplicación de 2,4-DP. Fruticultura Profesional, n. 60, p. 5-16, $1994 b$.

AGUSTÍ, M; JUAN. M.; SPERONI, C.; ANDREU, I.; ALMELA, V. Mejora de la calidad del fruto de melocotoneros y albaricoqueros mediante la aplicación de auxinas de síntesis. Valencia: Generalitat Valenciana, 1995. 19p.

AGUSTI, M.; ANDREU, I.; JUAN, M.; MEDINA, F.; ALMEIDA, V. Empleo Del 3,5,6-TPA para mejorar la calidad del fruto de melocotoneros y nectarinas.

Fruticultura Profissional, n. 81, p. 49-61, 1996.

AGUSTI, M.; JUAN, M.; ALMELA, V.; ANDREU, I.; SPERONI, C. Estimulo del desarrollo de los frutos de hueco. Valencia: Generalitat Valenciana, 1997. 78p.

AGUSTÍ, M; ANDREU, I.; JUAN M.; ALMELA, V; ZACARIAS, L. Effects of ringing branches on fruit size and maturity of peach and nectarine cultivars. Journal of Horticultural Science \& Biotechnology., v.73,n.4,p.537-540, 1998. 
AVIDAN, B., EREZ, A.. A reliable actinometric method for characterizing the light regime in plant canopier. Journal of the American Society for Horticultural Science, v.11, n.2, p.187-191, 1986.

BARBOSA, W. Desenvolvimento vegetativo e reprodutivo do pessegueiro em pomar compacto sob poda drástica. Piracicaba, 1989. 154p. Tese (Doutorado)-Universidade de São Paulo, Escola Superior de Agricultura "Luiz de Queiroz", Universidade de São Paulo.

BARBOSA, W.; CAMPO DALL'ORTO, F.A.; OJIMA, M.; SANTOS, R.R.; KALIL, G.P.C.; FAHL, J.L.; CARELLI, M.L.C. O pessegueiro em pomar compacto: IX. Dez anos de produção de cultivares sob poda drástica bienal. Pesquisa Agropecuária Brasileira, v. 34, n. 1, p. 69-76, 1999.

BASSOLS, M.C.M. Frutificação efetiva, germinação do pólen e número de grãos de pólen por antera em pessegueiro. Pelotas, UEPAE de Cascata, 1980. 3p.

BENITO, A.; CHIVITE, A.; LIZAR, B. Melacatonero: técnicas de mejora de la calidad de sus frutos. Fruticultura Profesional, n. 72, p. 67-70, 1995.

BLANCO, A. Aplicaciones de reguladores de crescimento em albaricoquero, cerezo y cinuelo. Fruticultura Profissional, n.30, p. 67-70, 1990.

BLEICHER, J.; TANAKA, H. Doenças do pessegueiro no Estado de Santa Catarina. 2.ed. Florianópolis: Empresa Catarinense de Pesquisa Agropecuária, 1982. 53p.

BORBA, M.R.C. Teores de carboidratos em pessegueiros (Prunus persica (L.) Batsch) submetidos a diferentes tipos de poda. Piracicaba, 2002, 51p. Dissertação (Mestrado)- Escola Superior de Agricultura “Luiz de Queiroz”, Universidade de São Paulo. 
CALLESSEN, O.; WAGENMAKERS, P.S. Effects of tree density, tree height and rectangulaity on growth, flowering, and fruit production. Acta Horticulturae, n.243, p. 141-148, 1989.

CAMPO DALL'ORTO, F.A.; OJIMA, M.; BARBOSA, W. Fruticultura: queda de frutos imaturos. O Agronômico, v. 43, p. 2-3, 1991.

CAMPO-DALL'ORTO, F.A.; OJIMA, M.;BARBOSA, W.;MARTINS, F.P. O nanismo do pessegueiro induzido pela enxertia no Damasqueiro-Japonês. Pesquisa Agropecuária Brasileira, v. 27, n.3, p.517-521, 1992.

CAMPO-DALL'ORTO, F.A.; OJIMA, M.;BARBOSA, W.;MARTINS, F.P. O nanismo do pessegueiro induzido pela enxertia no damasqueiro-japonês. Pesquisa Agropecuária Brasileira, v. 27, n.3, p.517-521, 1992.

CASTRO, P.R.C. Translocação de solutos orgânicos. I: FERRI, M.G.(Coord).Fisiologia Vegetal. São Paulo: EPU, 1985. cap.5, p.213-250.

CASTRO, P.R.C.; FACHINELLO, J.C. Aplicações de reguladores vegetais em fruticultura. Piracicaba:ESALQ; CENA, 1995. 43p. (ESALQ.CENA. Boletim Técnico, 2).

CASTRO, P.R.C.; VIEIRA, E.L. Aplicações de reguladores vegetais na agricultura tropical. Guaíba: Agropecuária, 2001, 132p.

CRANE, J.C. The role of hormones in fruit set and development. HortScience, v.4, p.108-111, 1969. 
CHALMERS, D. J.; MITCHELL, P. D. , VAN HEEK, L. Control of peach tree growth and productivity by regulated water supply, tree density, and summer pruning. Journal of the American Society for Horticultural Science, v.106, n.3, p.307-312, 1981.

DE JONG, T.M.; DAY, K.R.; DOYLE, J.F. Evaluating of training/pruning systems for peaches, plum and nectarine trees in California. Acta Horticulturae, n. 322, p. 99104, 1992.

DE VILLIERS, H.; CUTTING, J.G.M.; JACOBS, G.;STRYDOM, D.K. The effect of girdling on fruit growth and internal quality of 'Culembirg' peach. Journal of Horticultural Science, v.65, p.151-155, 1990.

EMPRESA BRASILEIRA DE PESQUISA AGROPECUÁRIA, Centro Nacional de Pesquisa de Fruteiras de Clima Temperado (Pelotas, RS).A cultura do pessegueiro. Pelotas, 1984. 156p.

EREZ, A. Growth control with paciobutrazol of peaches grown in a meadow orchard system. Acta Horticulturae, n.160, p.217-224, 1986.

EREZ, A. Peach meadow orchards. Acta Horticulturae, n.173, p.405-411, 1985.

Food and Agriculture Organization of the United Nations. FAOSTAT. Database results. Rome. Disponível na internet. http://www. Fao.org. (25 nov. 2004).

FAUST, M. Physiology of temperature zone fruit trees. New York: John Wiley, 1989. $338 \mathrm{p}$. 
FERRAZ, E. C. Apontamento de fisiologia vegetal. Piracicaba: Centro Acadêmico “Luiz de Queiroz”, n.2, p.100-131, 1985.

FLORE, J.A. Stone fruit. In: SCHAFFER, B.; ANDERSEN,P.C. Handbook of environmental physiology of fruits crops. Boca Raton: CRC Press, 1994. v.1,cap. 9, p. 233-270: Temperate crops.

FUERTES, M.C.; HERNÁNDEZ, M.B.D. Poda de frutales y técnicas de propagación y plantación. Madrid: Mundi-Prensa, 1995. 267p.

GOULD, H.P. Peach-growing. New York: MacMillan, 1923. 426p.

GOUVEIA, N.M. Estudo da diferenciação e crescimento de gemas florais de Coffea arabica L. Observações sobre a antese e maturação dos frutos. Campinas, 1984. 237p. Dissertação (Mestrado) - Universidade de Campinas.

GREULACH, V.A. Plant function and structure. New York: MacMillan, 1973. 575p.

HALL, D. O. , RAO, K. K. Fotossíntese. São Paulo: EPU, Ed. da Universidade de São Paulo, 1980. 89p.

HANSCHE, P. E.; HESSE, C. O. ,BEUTEL, J. Dwarf tree potential: “Just peach”. American Fruit Grower, v.99, n.8, p.12-17, 1979.

HANSCHE; HESSE, C.O. ,BERES, V. Estimate of genetic and environmental effects on several traits in peach. Journal of the American Society for Horticultural Science, v.97, n.1, p.9-12, 1972.

HEDRICK, U.P. The peaches of New York. New York: J.B. Lyon, 1916. 541p. 
HERTER, F.G.; ZANOL, G.C.; REISSER JÚNIOR, C. Características ecofisiológicas do pessegueiro e da amexeira. Informe Agropecuário, v.18, n.189, p.19-23, 1997.

HOPKINS, W.G. Introduction to plant physiology. New York: John Wiley, 1995. $464 \mathrm{p}$.

JACKSON, J. E. Light interception and utilization by orchard systems. Horticultural Reviews, n.2, p.208-267, 1980.

JANICK, J. A ciência da horticultura. Rio de Janeiro: Livraria Freitas Bastos, 1968. $485 \mathrm{p}$.

JRAIDI, B. Contribution a l'étude de 1 'adaptation varietale du pécher aux conditions de milleu: anomalies florales et réceptivité des ovules., 1983. 169p. These (Douteur)Université Paris.

JUAN, M.; CARREGUÌ, M.A.; ALMELA, V. Stimolo allo sviluppo delle ciliegie mediante applicazione di auxine di sintesi. Rivista di Frutticoltura, n. 11, p. 63-67, 1997.

KENDRICK, R.E. ,FLANKLAND, B. Fitocromo e crescimento vegetal. São Paulo: EPU, Ed. da Universidade de São Paulo, 1981. 76p.

LANG, G.A.; EARLY, J.D.; MARTIN, G.C. , DARNELL, R.L. Endo-, para-, and ecodormancy: physiological terminology and classification for dormancy research. HortScience, n.22, v.3, p.371-377, 1987.

LILIEN-KIPNIS, H.; LAVEE, S. Anatomical changes during the development of 'Ventura' peach fruits. Journal of Horticultural Science, v.46, p.103-110, 1971. 
LORETI, F.; PISANI, P.L. Peach and Nectarine Training Systems in High-Density lanting: new trends in Italy. Acta Horticulturae, n.322, p.107-118, 1992.

LUCKWILL, L.C. Reguladores de crescimento em la produccion vegetal. Barcelona: Oikos-tan, 1994. 91 p.

LLOYD, J.Y.; FIRTH, D.J. Effect of deloliation time on depth of dormancy and subsequent vegetative and reproductive development in low chill peaches. Acta Horticulturae, n.279, p.223-230, 1989.

MAGAlHÃES, A. C. N. Fotossíntese. In: FERRI, M. G. Fisiologia Vegetal. São Paulo: EPU, Editora da Universidade de São Paulo, 1979. p.117-167.

MARINI, P.M. Vegetative growth, yeld and fruit quality of peach as influenced by dormant pruning, summer pruning and summer topping. Journal of the American Society for Horticultural Science, v. 110, n.2, p. 133-139, 1985.

MARODIN, G.A.B.; SARTORI, A.S. Situação das frutas de caroço no Brasil e no mundo. In: SIMPÓSIO INTERNACIONAL DE FRUTAS DE CAROÇO: PÊSSEGO, NECTARINAS E AMEIXAS, Porto Alegre, 2000. Anais. Porto Alegre: UFRGS,DHS, 2000. p. 7-16.

MILLER, S. S. Summer pruning affects fruit quality and light penetration in young peach trees. HortScience, n.22, v.3, p.390-393, 1987.

MONET ,BASTARD. Les mecanismes de la floraison chez le pêcher. Bulletin Technical Information, n.248, p.173-176, 1970. 
MONET ,BASTARD. Morphologie végetale, morfogenès et croissance des abauches chez le pêcher (Prunus persica L. Batsch). Paris, Centre Recherche Académie Science, 1968. 266p.

NAKAMURA, C.H.; SCARPARE FILHO, J.A.;KLUGE, R.A. Avaliação preliminar do umezeiro como porta-enxerto para pessegueiro e nectarina. Revista Brasileira de Fruticultura, v.21, n.2, p. 116-118, 1999.

NIENOW, A.A. Comportamento morfológico, fenológico e produtivo de cultivares de pessegueiro (Prunus persica L. Batsch), submetidos a poda de renovação após a colheita, na região de Jaboticabal/SP. Jaboticabal, 1997. 179p. Tese (Doutorado)Faculdade de Ciências Agrárias,Universidade Estadual Paulista “Júlio de Mesquita Filho.",

NITSCH, J.P. Photoperiodism in wood plants. Proceedings of the American Society for Horticultural Science, n.70, p.526-544, 1957.

NORTH, M.; STADLER, J.D.; DE VILLIERS, H. Effect of cyanamide and girdling on yeld, fruit size and quality of the wet peach. South African Journal of Plant and Soil, v.5, n.4, p.224-226, 1988.

OJIMA, M.; CAMPO-DALL'ORTO, F.A.; RIGITANO, O.; TOMBOLATO, A.F.C. ; BARBOSA, W. Melhoramento da nectarina em São Paulo. I. Cruzamento de 1970: seleção nas gerações F1 e F2. Bragantia, n.42, p.1-14, 1984.

OLIEN, W.C. Analysis of orchard training systems for production potential na longterm stability. Acta Horticulturae, n.322, p.119-123, 1992.

PEDRO JÚNIOR, M.J.; ORTOLANI, A.A.; RIGITANO, O.; ALFONSI, R.R.; PINTO, H.S. ,BRUNINI, O. Estimativa de horas de frio abaixo de 7 e de $13^{\circ} \mathrm{C}$ para 
regionalização da fruticultura de clima temperado no estado de São Paulo.

Bragantia, n.38, p.123-130, 1979.

POWELL, L.E.;PRATTI, C. Growth promoting substances in the developing fruit peach (Prunus persica L. Batsch). Journal of Horticultural Science, v.41, p.331-348, 1966.

RASEIRA, A.;PEREIRA, J.F.M.; MEDEIROS, A.R.M.; CARVALHO, F.L.C. Instalação e manejo do pomar. In: MEDEIROS, C.A.; RASEIRA, M.C.B. A cultura do pessegueiro. Brasília:EMBRAPA, Serviço de Produção de Informação, 1998. cap.5, p. 130-160.

REICHARD, G.L Use of peach interstem to delay peach phenoly. Acta Horticulturae, n.395, p. 201-207, 1995.

REICHARD, G.L. Using interstem to delay bloom in peach. Compact Fruit Tree, v.25, p. 90-91, 1992.

RIGITANO, O. A cultura do pessegueiro. Rio de Janeiro: Ministério de Agricultura, Serviço de Documentação, 1945. 114p.

SACHS, S. A cultura do pessegueiro. Pelotas, CNPFT/EMBRAPA, 1984. 156p. (Circular técnica, 10).

SCARPARE FILHO, J.A.; MINAMI, K.; KLUGE, R. A. Intensidade de raleio de frutos de pessegueiro 'Flordaprince' conduzidos em pomar com alta densidade de plantio. Pesquisa Agropecuária Brasileira, v. 35, n.6, p. 1109-1113, 2000a . 
SCARPARE FILHO, J.A.; KLUGE, R.A.; JACOMINO, A.P. TESSARIOLI NETO, J. Comparação entre dois sistemas de condução de pessegueiros em pomar compacto. Revista Brasileira de Fruticultura, v.21, n.2 p.146-149, 1999.

SCARPARE FILHO, J.A.; KLUGE, R.A.; VICTORIA FILHO, R.; TESSARIOLI NETO, J.; JACOMINO, A.P. Comportamento de duas cultivares de pessegueiro com interenxerto de ameixeira 'Januária'. Pesquisa Agropecuária Brasileira, v.15, n.4, p. $757-765,2000 b$.

SEARLE, N.E. Physiology of flowering. Annual Review Plant Physiology, n.16, p.97$118,1965$.

SENO, H. Técnica para el mejoramento del cultivo de durazno en Bolivia. Cochabamba: Overseas Tedrinical Cooperation Agency, 1971. 247 p.

SHULMAN, Y.; NIR, G.; FANBERSTEIN, L. ,LAVEE, S. The effect of cianamide on the release from dormancy of grapevine buds. Scientia Horticultural, n.19, p.97104, 1983.

SIMÃO, S. Tratado de fruticultura. Piracicaba: Fealq, 1998. 760 p.

TAIZ,L.; ZEIGER,E. Plant physiology. 2.ed. Sunderland: Sinauer Associates, 1998. $792 \mathrm{p}$.

TAIZ, L. ; ZEIGER, E. Plant physiology. New York: The Benjamin/Cummings Publ., 2002. 565p. 
TOMBESI, A. ,BELLEGGIA, S. L'influenza dell'intensità di illuminazione della chioma sulla differenziazione delle gemme a fiore e sulla qualità delle peache, $\mathrm{cv}$. 'Flavorcrest'. Rivista della Ortoflorofruticultures Italiana, n.70, p.297-306, 1986.

TOMBESI, A. Tipiche variazione dell strutura dell'apice di pesco dalla estadio indiferrenziato a quelo riproduttivo. Rivista Ortoflorofrutticoltura Italiana, n.49, p.401-421, 1965.

VIEIRA, M. R. Uso do regularos vegetal 2,4-DP (éster butilglicol do ácido 2,4diclorofenoxipropiônico) e do anelamento de ramos visando a melhoria na qualidade de frutos de pessegueiro (Prunus persica (L.) Batsh). Piracicaba, 2003, 54p. Dissertação (Mestrado)- Escola Superior de Agricultura “Luiz de Queiroz”, Universidade de São Paulo.

WARRINER, C. L.; JOHNSON, J. L. ,SMITH, M. W. Comparation of the initiation and development of 'Redhaven' peach flowers in standard and meadow orchard trees.

Journal of the American Society for Horticultural Science, n.110, v.3, p.379-383, 1985.

WESTWOOD,M.N. Temperature-zone pomology. San Francisco: W.H. Freeman, 1978.428 p.

WILLS, R.; MACGLASSON,B.; GRAHAM,D.; JOYCE, D. Introducción a la fisiología y manipulación poscosecha de frutas, hortalizas y plantas ornamentals. Zaragoza. 1998. 240p. 